\title{
$7 \mathrm{~mm} \cdot 106$
}

Manganese Deposits of Western Utah

G E O L O G I CA L S U R VEY BULLETIN 979-A

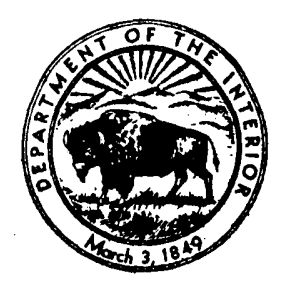

QE75

BQ

eos C.b 

Manganese Deposits of Western Utah

By MAX D. CRITTENDEN, JR.

MANGANESE DEPOSITS OF UTAH, PART 1

GEOLOGICAL SURVEY BULLETIN 979-A

$A$ report on known deposits

west of the 111th

meridian

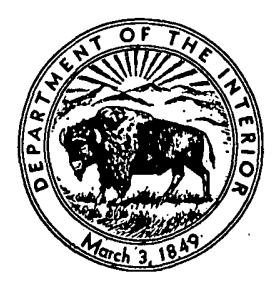


UNITED STATES DEPARTMENT OF THE INTERIOR

Oscar L. Chapman, Secretary

\section{GEOLOGICAL SURVEY}

W. E. Wrather, Director

For sale by the Superintendent of Documents, U. S. Government Printing Office Washington 25, D. C. - Price 50 cents (paper cover) 


\section{CONTENTS}

Abstract
Introduction
Occurrence and age of the deposits
Mineralogy
Descriptions of the manganese minerals
Oxides
Carbonates
Silicate.

Relative stability and manganese content................... 10

Oxidation and enrichment. .

Classification and origin of the deposits........... 11

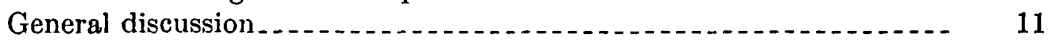

Syngenetic deposits.............. 13

Bedded deposits.......... 13

Spring deposits........ 14

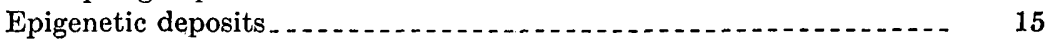

Oxidized hydrothermal deposits . . . .

Deposits of oxides of undetermined origin ................ 16

Reserves and future outlook . .

Descriptions of individual deposits . .

Beaver County ...

Susie Q claims . . . .

Black Rock (Shotwell) deposit.

Black Jack (Skougard) claims.

Steelville prospect

Spor property

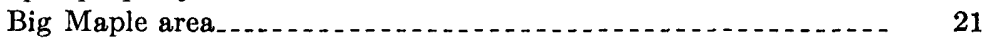

Cache County ............ 21

Blacksmith Fork area...... 21

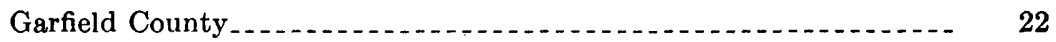

Fullmer prospect.

Hawkins claims . .

Unnamed prospect........... 22

Iron County

Black Jack (Gregory) claims.

Clove prospect...... 23

Blackhawk and Joe Louis claims . . _ _.

Lucky Joe claim......... 24

Taylor prospect.

Modena locality

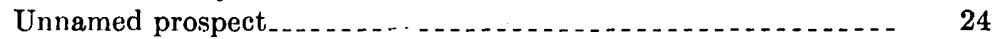


Descriptions of individual deposits-Continued Pago

Juab County

Abraham Hot Spring deposit_._. 24

Black Jack (Neilson) claims _._. 25

Black Jack (Kendall-Duvall) claims _ _ .

Orme property

Black Ledge claims _... 27

Topaz Mountain locality _. 27

Juab and Millard Counties _.

Detroit district._.

Staats and Pratt mines (Black Boy group) 28

Guy group (Black Jack mine) 30

Last Chance property 30

Black Diamond mine ............. 31

Martha prospect._... 31

Black Hawk claim. 31

Verdun claim .

Manganese King and Manganese King No. 1 claims_..... 31

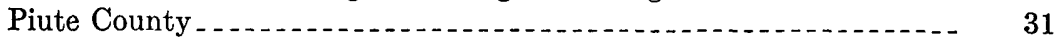

Blue Miami Moon No. 1 claim _... 31

Blackbird claims . .

Dry Canyon claims. 32

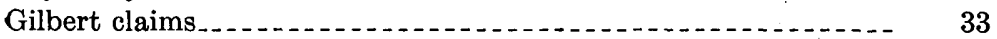

Rich County 33

Lakeview claims_._. 33

Salt Lake County

Manganese Lode property

Evans lime quarry

Michigan-Utah property 35

Sanpete County 35

Unnamed prospect._. 35

Sevier County 36

Yellow Hornet property 36

Noonday prospect. 36

Jumbo prospect

Georgia mine..... 36

Summit County 36

Unnamed prospect._. 36

Park City district._. 37

Ontario mine 37

Silver.King property

Tooele County ... 37

Ophir district.

Ophir Hill mine. 37

Columbia district. 38

Benmore mine. 38

Sharp mine 38 
Descriptions of individual deposits-Continued . Page

Tooele and Juab Counties _._. 39

Erickson district._._._. 39

Black Rock claims._. 40

Black Jack (Morgan-Cromar) claims

Deer Trail claims._._. 43

Indian Boy claim

Utonia claim

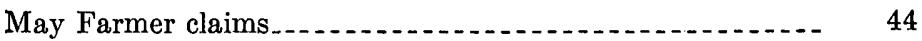

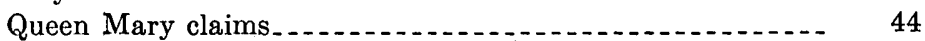

Utah County _..._.

Wildcat mine._........ 44

Trotter mine._._._. 46

Spalding claims_._._. 47

Queen of the West claim...... 48

Silver Hill property

Utah and Juab Counties._. 48

Tintic district...... 48

Tip Top tunnel

Oxen mine

Tintic Standard mine.

Fields claims........ 52

Black Jack (Empire) mine 52

White Cloud claim 53

Black Jack (Winberg) property 54

Iron Blossom mine... 54

Iron King mine

Apex Standard claims

North Tintic claims..._. 55

Wasatch County

Grey Hawk property 55

Eàst Star No. 1 property 55

Washington County 56

Black Beauty No. 1 claim. 56

Wallace claims. 57

Weber County 57

Payday claims...5 57

Selected bibliography

Index

\section{ILLUSTRATIONS}

Plate 1. Map showing distribution of manganese deposits in western Utah...... In pocket

FIGURE 1. Chart showing production of manganese ore in Utah, 19001945

2. Chart showing discoveries and price of manganese ore in western Utah, 1914-42... 


\section{TABLES}

TABLE 1. Manganese-ore production in western Utah by grade, 1915-45.

2. Manganese-ore production in western Utah by year, $1915-45$

3. Shipments of manganese ore and manganiferous ore from western Utah, 1915-45.

4. Estimated reserves of manganese ore in western Utah

5. Range in composition of samples of water from Abraham Hot Spring, Juab County, Utah

6. Assay of metallurgical sample from Black Jack (KendallDuvall) claims, Juab County.

7. Manganese-ore production, Staats and Pratt mines, Detroit district, Juab and Millard Counties

8. Manganese-ore production, Guy group (Black Jack mine), Detroit district.

9. Manganese-ore production, Evans lime quarry, Salt. Lake County

10. Manganese-ore production, Georgia mine, Sevier County ....

11. Manganese-ore production, Ophir Hill mine, Ophir district,

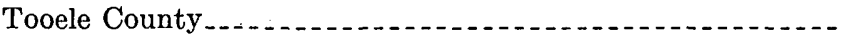

12. Manganese-ore production, Benmore and Sharp mines, Columbia district, Tooele County.

13. Manganese-ore production, Black Rock claims, Tooele and Juab Courties . . . . . . . . . . .

14. Manganese-ore production, Black Jack (Morgan-Cromar) claims, Tooele and Juab Counties.....................

15. Assay of metallurgical samples from Black Jack (Morgan-

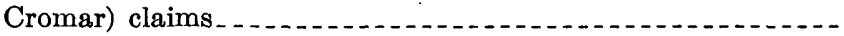

16. Manganese-ore production, Deer Trail claims, Erickson district,

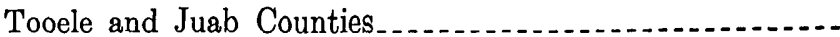

17. Manganese-ore production, Indian Boy claim, Erickson district

18. Manganese-ore production, Wildcat mine, Utah County ......

19. Manganese-ore production, Trotter mine, Utah County .......

20. Manganese-ore production, Tip Top tunnel, Tintic district, Utah and Juab Counties..................

21. Assay of metallurgical samples from Tintic Standard mine, Tintic district. . . . . . . . . .

22. Manganese-ore production, Black Jack (Winberg) property, Tintic district . . . . . . . . . . . . . . . . . . . . . . . 


\title{
MANGANESE DEPOSITS OF UTAH
}

\section{PART 1: MANGANESE DEPOSITS OF WESTERN UTAH}

\author{
$\mathrm{By}_{2}^{\sigma}$ Max D. Crittenden, JR.
}

\begin{abstract}
Deposits of manganese are widely distributed in Utah west of the 111th meridian. From 1915 through 1945 a total of 72,822 long tons of manganese ore with an average grade of 25.5 percent $\mathrm{Mn}$ was produced, more than half during World War II. Most of this material is of the type usually classed as manganiferous ore or ferruginous manganese ore and was used by blast furnaces within the State.

The deposits are divided into two groups according to their manner of deposition. (1) Syngenetic deposits, in which the manganese was originally deposited at the same time as the enclosing rocks, include bedded deposits intercalated with sedimentary rocks and deposits interbedded with tufa formed by chemical precipitation from thermal springs. (2) Epigenetic deposits, in which the manganese was introduced into the enclosing rocks after their formation, include hydrothermal vein and replacement deposits whose oxidized zones have yielded most of the manganese produced.

The known manganese deposits in western Utah contain more than 360,000 long tons of material with a manganese content ranging from 10 to more than $\mathbf{4 0}$ percent. However, most of the material containing 10 to 20 percent $\mathrm{Mn}$ is submarginal, and at least half of that containing 20 to 30 percent $\mathrm{Mn}$ cannot be mined economically except during periods of very high prices. About 25,000 long tons, averaging 20 to 30 percent $\mathrm{Mn}$, is probably a reasonable estimate of the measured ore reserves, but new discoveries or higher prices might double this figure.

In the report, more than 75 deposits and prospects are described on the basis of first-hand examination or information compiled from the files of the U.S. Geological Survey and the U. S. Bureau of Mines.
\end{abstract}

\section{INTRODUCTION}

Deposits of manganese ore are widely distributed in western Utah. They extend from Bear Lake near the Wyoming border to St. George near the Arizona border and from Modena in western Iron County to Marysville near the west edge of the high plateaus. Although the deposits are widely scattered (pl. 1), the production by counties shows clearly that relatively few properties and districts have yielded nearly all the ore produced.

The area covered by this report includes roughly that part of Utah west of the 111th meridian. Most of this area is a part of the Basin and Range physiographic province; however, certain deposits in Sevier, 
Piute, and western Garfield Counties are on the west edge of the Plateau province of Utah and Colorado.

This report is a compilation of all the data available on the manganese deposits of western Utah; consequently it contains material from various sources. Many of the deposits were examined by geologists of the Geological Survey during the period 1940-45 as part of the strategic-mineral investigations carried on by the Survey and the U. S. Bureau of Mines. The accounts written during this work form the basis for many of the mine descriptions. In the spring of 1946 the author spent parts of 3 months in the field, obtaining information on production and reserves and visiting properties on which additional geologic data were needed. Information concerning some of the deposits was compiled from the files of the Bureau of Mines and from the literature cited.

The following geologists of the Geological Survey contributed material used in this report: A. A. Baker, G. L. Bell, M. W. Cox, D. C. Duncan, A. E. Granger, W. H. Myers, R. J. Roberts, A. F. Shride, J. A. Straczek, J. H. Wiese, and M. E. Willard.

It is a pleasure to acknowledge the wholehearted cooperation of the many mine owners and operators who supplied information and who often accompanied the geologists to their properties. P. T. Allsman and W. H. King; of the Bureau of Mines office in Salt Lake City, made helpful suggestions concerning the occurrence and origin of deposits with which they are personally acquainted. The author is particularly indebted to D. F. Hewett, W. T. Pecora, J. A. Straczek, E. T. McKnight, and S. K. Neuschel for critical reading of the manuscript and for helpful and constructive discussions of the classification and origin of the deposits.

\section{HISTORY OF MINING AND PRODUCTION}

Although there was earlier production from eastern Utah (Pardee, 1921 , p. 179), there was no recorded production of manganese ore ${ }^{1}$ from western Utah until 1915, when 55 tons of ore was shipped from the Michigan-Utah mine in the Little Cottonwood district, Salt Lake County. From 1915 through 1918, the high prices and urgent need for manganese created by World War I resulted in the discovery of many new manganese deposits in western Utah, but most of them were not developed rapidly enough to yield a large production before the end of the war. Consequently, during the period 1915-18, mines

1 It has been accepted practice in the manganese industry to restrict the term "manganese ore" to material containing 35 percent or more manganese and to use the terms "ferruginous manganese ore" and "manganiferous ore" in referring to material containing 5 to 35 percent manganese. In this report, however, all material shipped for its manganese content will be called manganese ore, regardleos of the amount of manganese present or whether it was produced at a profit. 
in the western part of the State produced only 3,113 long tons of ore out of the 12,000 long tons produced in Utah and the 476,361 long tons produced in the United States.

Production in western Utah had virtually ceased by the end of 1918 and was not resumed until 1924. From 1924 to 1930 activity increased steadily, stimulated by the industrial boom and by a local market at the Columbia Steel plant near Provo. More than 19,000 long tons of ore was produced from Utah, Salt Lake, Tooele, Millard, and Juab Counties in the years 1924-31. There was no production from 1932 to 1934, and only a small production in 1935. Output was intermittent from 1936 to 1941 , ranging from 1,000 to 5,000 tons a year. Increased prices and the convenient market provided by the Government stockpiling program, coupled with the exploration program of the Bureau of Mines and the Geological Survey, resulted in a production of more than 20,000 long tons in 1943 and 12,000 long tons in 1944, nearly all of which came from mines in the Detroit, Tintic, and Erickson districts. In 1945 the Pratt mine in the Detroit district was the only producer.

During the period 1915-45 the manganese mines of western Utah produced 72,822 long tons of ore, distributed as indicated in tables 1 and 2. Detailed production figures by mines are included in table 3.

TABLE 1.-Manganese-ore production in western Utah by grade, 1915-45

\begin{tabular}{r|r|r|r|r|r|r}
\hline & \multicolumn{5}{|c}{ Percent Mn } \\
\cline { 2 - 4 } & Less than 10 & $10-20$ & $20-30$ & $30-40$ & More than 40 & Total \\
\hline Production, in long tons. & 496 & 1,693 & 56,083 & $\cdot 13,718$ & .832 & 72,822 \\
\hline
\end{tabular}

A verage grade 25.5 percent $\mathrm{Mn}$.

TABLE 2.-Manganese-ore production in western Utah by year, 1915-45.

\begin{tabular}{|c|c|c|c|}
\hline Year & Jong tons & Year & Long tons \\
\hline $\begin{array}{l}1915 \\
1916 \\
1917 \\
1918 \\
1924 \\
1925 \\
1926 \\
1927 \\
1928 \\
1930\end{array}$ & $\begin{array}{r}55 \\
763 \\
896 \\
1,399 \\
116 \\
1,212 \\
46 \\
239 \\
286 \\
6,030 \\
10,673 \\
1,427\end{array}$ & $\begin{array}{r}1935 \\
1936 \\
1937 \\
1940 \\
1941 \\
1942 \\
1943 \\
\text { Total }\end{array}$ & $\begin{array}{r}190 \\
4,548 \\
3,468 \\
113 \\
1,906 \\
433 \\
1,435 \\
20,731 \\
12,622 \\
4,234 \\
72,822\end{array}$ \\
\hline
\end{tabular}


TABLE 3.-Shipments of manganese ore and manganiferous ore from western Utah, 1915-45

[Data from records of U. S. Bureau of Mines, supplemented by information obtained in the field]

\begin{tabular}{|c|c|c|c|c|c|}
\hline Year & County & Mine & Shipper & $\begin{array}{l}\text { Produc- } \\
\text { tion (long } \\
\text { tons, } \\
\text { natural } \\
\text { weight) }\end{array}$ & $\begin{array}{l}\text { Grade } \\
\text { (percent } \\
\text { Mn) }\end{array}$ \\
\hline 1915 & Salt Lake. & Michigan-U & $\begin{array}{l}\text { Michigan-Utah Cons } \\
\text { Mines Co. }\end{array}$ & 55 & 38.4 \\
\hline \multirow[t]{5}{*}{1916} & Salt Lake. & \multirow{2}{*}{ Michigan-Utah. } & \multirow{5}{*}{$\begin{array}{l}\text { Michigan-Utah Consolidated } \\
\text { Mines Co } \\
\text { Triangle Mining Co } \\
\text { Chief Consolidated Mining Co.. } \\
\text { Charles S. Wilkes................. }\end{array}$} & 66 & 41 \\
\hline & & & & 400 & \\
\hline & Utah & Tip Top & & 147 & $40-44$ \\
\hline & Sevier.... & Georgia..... & & 150 & 32 \\
\hline & Total. & & & 763 & \\
\hline \multirow[t]{4}{*}{1917} & Utah & Tip Top.- & Thomas L. McCarthy & 714 & $\begin{array}{r}35 \\
10-35\end{array}$ \\
\hline & Salt Lake & Michigan-U & \multirow{3}{*}{$\begin{array}{l}\text { Michigan-Utah Consolidated } \\
\text { Ophir Hill Consolidated Mining } \\
\text { Co. }\end{array}$} & 100 & $10-35$ \\
\hline & Tooele.. & Ophir Hill. & & 46 & 35 \\
\hline & Total & & & 896 & \\
\hline \multirow[t]{3}{*}{1918} & $\begin{array}{l}\text { Sevier.... } \\
\text { Utah } \\
\text { Tooele..... }\end{array}$ & \multirow{3}{*}{$\begin{array}{l}\text { Georgia } \\
\text { Tip Top } \\
\text { Black Jack (Morgan- } \\
\text { Cromar). } \\
\text { Ophir Hill }\end{array}$} & \multirow{3}{*}{$\begin{array}{l}\text { A. Bjorman } \\
\text { Chief Consolidated Mining Co.. } \\
\text { Thomas L. McCarthy } \\
\text { Ophir Hill Consolidated Mining } \\
\text { Co. }\end{array}$} & $\begin{array}{l}250 \\
664 \\
125\end{array}$ & $\begin{array}{l}50 \\
35+ \\
40.3\end{array}$ \\
\hline & Do. & & & 360 & $35+$ \\
\hline & Total & & & 1,399 & \\
\hline \multirow[t]{2}{*}{1924} & $\begin{array}{l}\text { Millard... } \\
\text { Utah........ }\end{array}$ & \multirow[t]{2}{*}{\begin{tabular}{|l} 
Guy group \\
Trotter.................
\end{tabular}} & \multirow[t]{2}{*}{$\begin{array}{l}\text { H. S. Joseph } \\
\text { S. D. and Dewitt Trotter.... }\end{array}$} & $\begin{array}{l}37 \\
79 \\
\end{array}$ & \multirow[t]{2}{*}{$\begin{array}{l}27 \\
14.3\end{array}$} \\
\hline & Total & & & 116 & \\
\hline \multirow[t]{3}{*}{1925} & $\begin{array}{l}\text { Juab and Mil- } \\
\text { lard. }\end{array}$ & \multirow{3}{*}{\begin{tabular}{|l|}
$\begin{array}{l}\text { Staats-Pratt and Guy } \\
\text { group. } \\
\text { Trotter }\end{array}$ \\
Sharp do
\end{tabular}} & \multirow{3}{*}{ 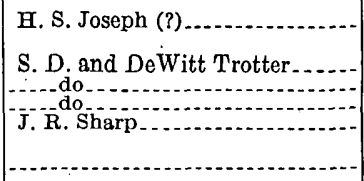 } & 500 & \multirow{3}{*}{$\begin{array}{l}25 \\
37.95 \\
13.67 \\
8.8 \\
30.3\end{array}$} \\
\hline & 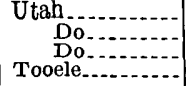 & & & $\begin{array}{r}50 \\
102 \\
496 \\
64\end{array}$ & \\
\hline & Total & & & 1,212 & \\
\hline 1926 & Salt Lake. & Manganese Lode.. & Sterling and Williams & 46 & 25.2 \\
\hline \multirow[t]{2}{*}{1927} & $\begin{array}{l}\text { Utah. } \\
\text { Do......... } \\
\text { Salt Lake- } \\
\text { Juab and Mii- } \\
\text { lard. }\end{array}$ & $\begin{array}{l}\text { Trotter } \\
\text { Silver Hill } \\
\text { Evans lime quarry } \\
\text { Stauts-Pratt and Guy } \\
\text { Group (?). }\end{array}$ & \multirow[t]{2}{*}{ 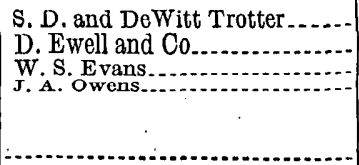 } & $\begin{array}{r}163 \\
33 \\
22 \\
21\end{array}$ & \multirow[t]{2}{*}{$\begin{array}{l}11.96 \\
17.0 \\
24.9 \\
23.1\end{array}$} \\
\hline & Total. & & & 239 & \\
\hline 1828 & Juab_ & Staats-Pratt... & Fred Staats...... & 286 & 24.5 \\
\hline \multirow[t]{2}{*}{1929} & $\begin{array}{r}\text { Juab } \\
\text { Do...... } \\
\text { Do.... } \\
\text { Do.... } \\
\text { Utah. }\end{array}$ & 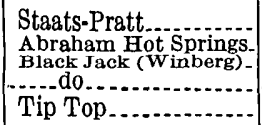 & \begin{tabular}{|c|} 
Fred Staats \\
Thomas E. Conatwin \\
Chief Consolidated Mining Co..
\end{tabular} & $\begin{array}{r}4,084 \\
40 \\
47 \\
41 \\
1,818\end{array}$ & \multirow[t]{2}{*}{$\begin{array}{l}22 \\
19.4 \\
35.2 \\
37 \\
21.48\end{array}$} \\
\hline & Totel & & & 6,030 & \\
\hline \multirow[t]{2}{*}{1930} & 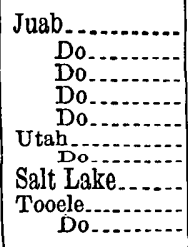 & $\begin{array}{l}\text { Staats........... } \\
\text { Abraham Hot Springs } \\
\text { Rising Sun } \\
\text { Black Jack (Winberg) } \\
\text { Pratt_... } \\
\text { Tip Top } \\
\text { Wildcat } \\
\text { Evans lime quarry } \\
\text { Benmore } \\
\text { Indian Boy }\end{array}$ & 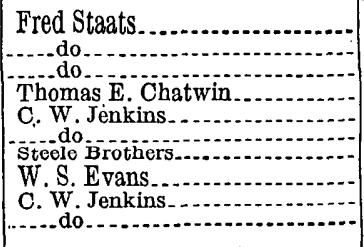 & $\begin{array}{c}7,828 \\
674 \\
162 \\
318 \\
33 \\
338 \\
206 \\
186 \\
878 \\
60\end{array}$ & \multirow[t]{2}{*}{$\begin{array}{l}22.6 \\
17+ \\
35.23 \\
35.2 \\
\\
24.66\end{array}$} \\
\hline & & & & 10,673 & \\
\hline
\end{tabular}


TABLE 3.-Shipments of manganese ore and manganiferous ore from western Utah, 1915-45-Continued

[Data from records of U. S. Bureau of Mines, supplemented by information obtained in the field]

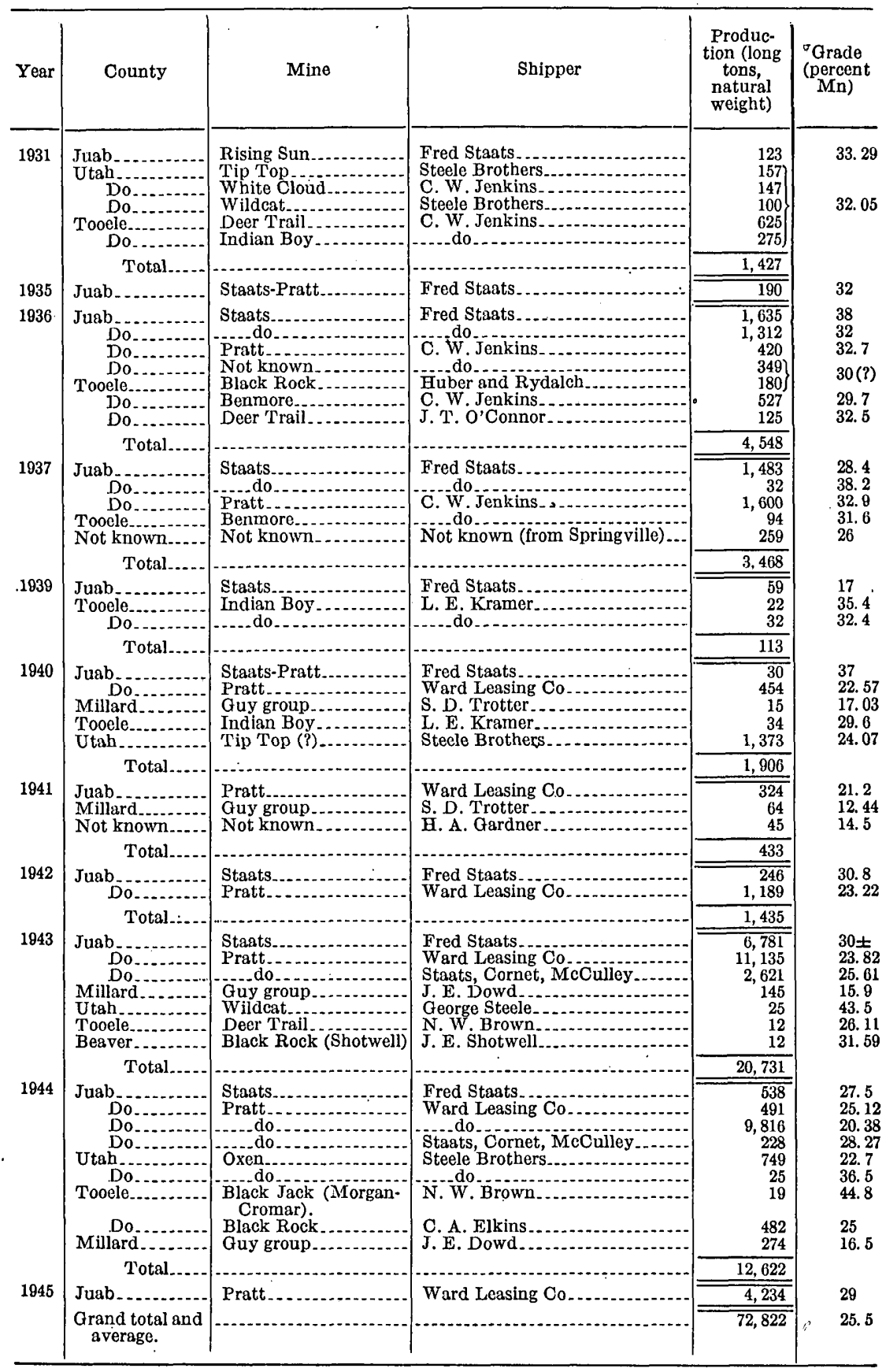


The most significant factor in the development of manganese mines in Utah has been the existence of a local market for the type and grade of ore available. The Columbia Steel Co., at Ironton, Utah, and the Colorado Fuel and Iron Co. at Pueblo, Colo., purchased and used more than three-fourths of the manganese ore produced in Utah from 1900 to 1940 . From 1943 to 1945 , virtually all the ore produced in Utah was used by the Geneva Steel.Co., at Provo. The proximity of mines in western Utah to these industrial consumers has favored the use of local ore, which can be mined and shipped at low cost, over the importation of higher-grade ore from other parts of the country or from foreign sources. 'This peculiarly favorable situation has resulted in the continued though sporadic existence in Utah of an industry that might not otherwise have been successful.

The graph of production (fig. 1) shows the intermittent nature of the manganese-mining industry in Utah.

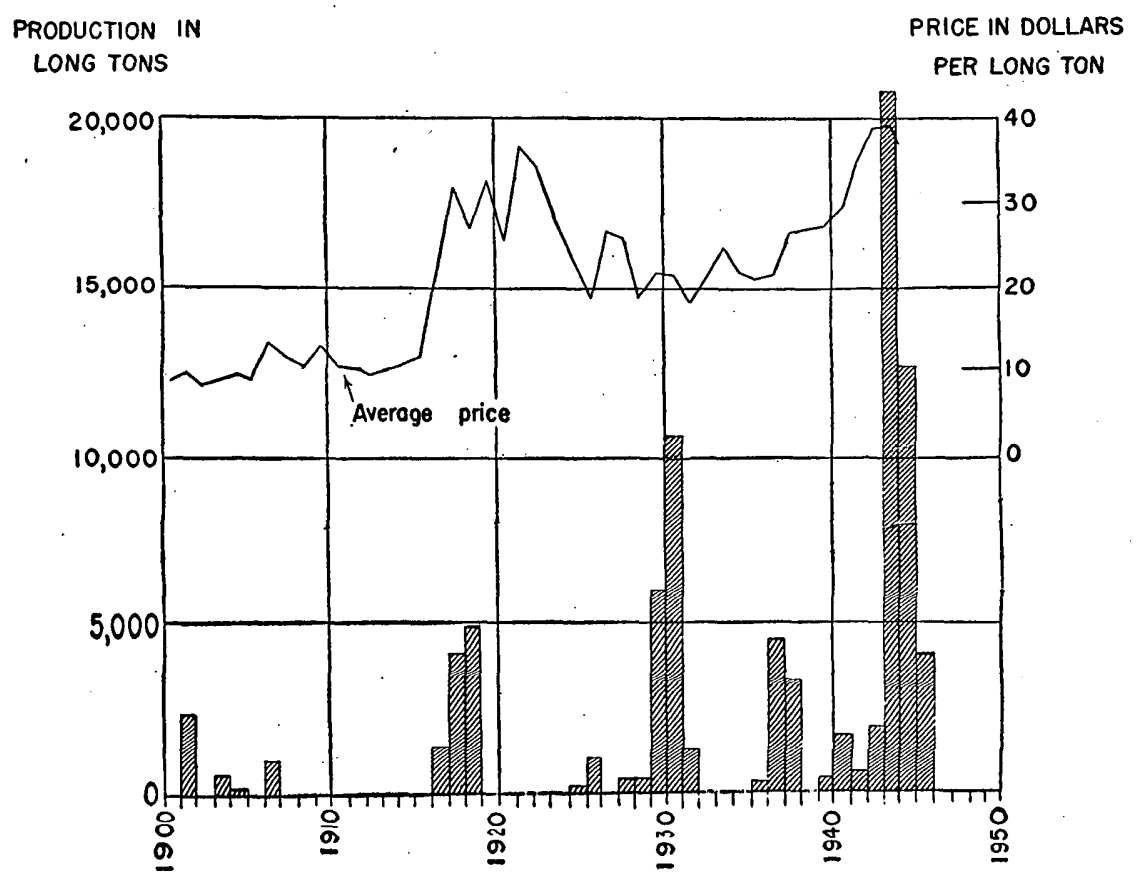

FIGJkE 1.- Chart showing production of manganese ore in Utah, 1900-1945. Data from U. S. Burcau of Mines Minerals Yearbook. Includes manganiferous and ferruginous ore; average cumulative grade, 25.5 percent $\mathrm{Mn}$.

\section{OCCURRENCE AND AGE OF THE DEPOSITS}

Four types of manganese deposits have been recognized in western Utah. The most important, and by far the greatest number, are partly oxidized deposits of hydrothermal manganese carbonate 
closely associated with deposits of copper, lead, zinc, or silver. Most of the deposits are in well-known mining districts, and the manganese is found in the same kind of vein and replacement bodies and in the same diversity of rocks as the precious and base metals.

A second mode of occurrence that is widespread but of little economic importance is as veins of manganese oxide not associated with precious- and base-metal deposits. Most of these veins cut volcanic: rocks and are a fraction of an inch to a few inches wide and a few feet to a few tens of feet long. Only rarely are they sufficiently thick to be minable, and none have been mined deeply enough to expose primary ore minerals.

Two other types of deposits have been noted but are of minor value. (1) Manganese occurs in sedimentary rocks, either as separate lenses or beds or as a disseminated cement in sandstone or conglomerate. (2) Manganese oxides also are found in a broad, low mound of tufa surrounding an active thermal spring near Abraham, Juab County, and in calcareous tufa from an extinct spring near Camp Williams, Salt Lake County.

The manganese deposits of western Utah are nearly as diverse in age as in occurrence. As will be pointed out more fully in the discussion of origin, the matter of age is complicated by ever-present surface oxidation that has affected every manganese deposit during Recent time. Many deposits, in fact, contain no "ore" other than secondary oxides. However, considering only the time at which the primary ore was localized, they range in age from Upper Triassic (Wallace group of claims in Washington County) to Recent (Abraham Hot Spring deposit in Juab County). Most of the deposits associated with precious or base metals are of Tertiary age.

The depth at which the deposits were formed is also highly variable. The spring deposits, obviously, were formed at the present surface, and the older bedded deposits were formed on an ancient land surface or in an ancient sea. In contrast, the hydrothermal deposits in mining districts were formed in fractures and fault zones within the earth at a distance of several hundred or perhaps several thousand feet below the land surface. Erosion has since removed the material above the deposits and lowered the land surface to its present level.

\section{MINERALOGY}

Although more than 200 manganese-bearing minerals have been described, less than a dozen are significant as commercial sources of manganese. The minerals most commonly found in western Utah are the oxides pyrolusite, psilomelane, cryptomelane, and wad; the carbonates rhodochrosite and manganoan calcite or manganoan dolomite; and the silicate rhodonite. More than 90 percent of the ore 
shipped from western Utah through 1945 consisted of oxides. The remainder was almost entirely manganese carbonate.

\section{DESCRIPTIONS OF THE MANGANESE MINERALS}

The following brief descriptions of the manganese minerals that occur in western Utah are based largely on field examination. Relatively little material has been examined in the laboratory. More complete lists of manganese minerals and their properties are to be found in mineralogical textbooks and in the publications mentioned in the bibliography.

\section{OXWDES}

The so-called "manganese oxide" minerals were recently investigated in the chemical laboratory of the Geological Survey, and a preliminary report describing the results of this study was published by Fleischer and Richmond (1943). It was found that these minerals can best be differentiated and identified by means of their X-ray patterns supplemented by qualitative chemical tests. As a result of this work, it is now possible to identify the manganese oxide minerals in the laboratory with reasonable certainty. As Fleischer and Richmond point out, however, it is often impossible to determine in the field what mineral or minerals are present. They recommend the following general terms for field use:

1. "Psilomelane type." This term should be used for massive, hard, heavy material not specifically identified. It includes several distinct minerals or mixtures of them; hence no chemical formula should be given.

2. "Wad." This term should be used for massive, soft material of low apparent specific gravity, not examined in the laboratory. Such material may be any one of several distinct minerals, may be a mixture, or may be unidentifiable; hence no chemical formula should be given.

The following specific minerals are known to occur in western Utah:

Pyrolusite, $\mathrm{MnO}_{2}$.-This is the commonest manganese oxide; commonly it contains a little adsorbed water. It is soft, ranges from iron gray to black, and gives a black streak. Its mode of occurrence is variable; it may be (1) crystalline, with a marked metallic luster; (2) compact, fine-grained, and dull; or (3) botryoidal, in radiating layers.

Cryptomelane, $K_{8} \mathrm{O}_{16}$ (?).-In the formula for this mineral, $\mathrm{R}$ equals chiefly $\mathrm{Mn}^{++++}$but also $\mathrm{Mn}^{++}, \mathrm{Zn}$, or $\mathrm{Co}$; most samples contain 2 to 4 percent of adsorbed water. This is the commonest of the minerals of the psilomelane type. It was identified as the principal 
mineral at the Wildcat mine in Utah County, where it occurs in slaggy, cavernous masses. These masses are dull black on the outside owing to a coating of soft wad, but on freshly broken surfaces the material is dense. fine-grained, and bluish gray.

Psilomelane, $\mathrm{BaMn}{ }^{++} \mathrm{R}_{8} \mathrm{O}_{18} .2 \mathrm{H}_{2} \mathrm{O}$.- In this formula, $\mathrm{R}$ equals chiefly $\mathrm{Mn}^{++++}$; the water is essential in the molecular structure. Psilomelane is known to occur in the Detroit district and also at the Black Jack (Kendall-Duvall) claims and the Orme mine, all in Juab County. It occurs in dense, fine-grained masses, in botryoidal, radiating masses interlayered with pyrolusite, and in slaggy or cellular masses. Although it has not been specifically identified from other localities, the barium content of psilomelane-type ore from other mines suggests that psilomelane is widespread in western Utah.

Manganite, $\mathrm{MnO}(\mathrm{OH})$.- Manganite was found by Fleischer and Richmond to be a comparatively rare mineral. It was not identified during the present study, but was thought to occur in the San Francisco district, Beaver County (Butler, 1913, p. 98).

Braunite, $3(\mathrm{Mn}, \mathrm{Fe})_{2} \mathrm{O}_{3} \cdot \mathrm{MnSiO}_{3}$.-Braunite is reported by the U. S. Bureau of Mines from the Black Jack claims of Kendall and Duvall in Juab County.

Bixbyite, $\mathrm{Mn}_{2} \mathrm{O}_{3}$.-Minute crystals of bixbyite are found on topaz crystals in the Topaz Mountains, in northern Juab County (see p. 27).

\section{Carbonates}

Rhodochrosite, $\mathrm{MnCO}_{3}$. - Usually this mineral contains some $\mathrm{Ca}$, $\mathrm{Mg}$, or Fe. It is isomorphous with calcite, dolomite, and siderite (see following paragraph).

Manganoan calcite, manganoan dolomite, and manganoan siderite; $\mathrm{CaCO}_{3}, \mathrm{CaMg}\left(\mathrm{CO}_{3}\right)_{2}$, and $\mathrm{FeCO}_{3}$. - Rhodochrosite and these manganoan carbonates, containing up to 50 percent $\mathrm{MnCO}_{3}$, are the most abundant primary manganese minerals in western Utah. They occur as gangue minerals in many precious- and base-metal deposits and have been found beneath the manganese oxides wherever the primary minerals have been exposed by mining. They vary from pale cream to pink in color and occur as (1) fine-grained structureless material; (2) coarse, cleavable masses; (3) botryoidal, layered masses of variable composition; or (4) rhombohedral crystals lining veins and vugs.

\section{SILICATE}

Rhodonite, $\mathrm{MnSiO}_{3}$.-Usually this mineral contains some $\mathrm{Ca}, \mathrm{Mg}$, or Fe. Rhodonite occurs in the veins of the Erickson district in Tooele and Juab Counties, and it has been reported from the Ontario mine in the Park City district (Boutwell, 1912, p. 113). 


\section{RELATIVE STABILITY AND MANGANESE CONTENT}

The manganese minerals differ widely in their stability under oxidizing conditions. Pyrolusite is probably the most stable and is the oxidation product formed from most other minerals when they are exposed to the atmosphere. For this reason it is found in virtually every manganese deposit. Other oxide minerals, such as psilomelane, cryptomelane, and braunite, also are relatively stable, but even these minerals are commonly covered by thin sooty films of pyrolusite except where freshly broken. In contrast, all the manganese carbonates and the silicate are highly unstable under surface conditions and oxidize rapidly to one or more minerals of the oxide group.

The manganese content and the resulting value of a particular ore are determined both by the relative proportion of the manganese mineral to the gangue and by the amount of manganese in the ore mineral itself. For example, an ore which consists of three parts pyrolusite and one part barren wall rock will assay about 46 percent $\mathrm{Mn}$, whereas another ore consisting of three parts psilomelane and one part barren rock may assay only about 30 percent $\mathrm{Mn}$. An ore containing a similar proportion of manganoan calcite might assay only about 10 percent $\mathrm{Mn}$.

The chemical nature of the manganese mineral also influences the value of the ore. Rhodochrosite and the manganoan carbonates are readily converted to oxides by roasting, and the grade is increased by driving off the $\mathrm{CO}_{2}$. Rhodonite, on the other hand, is not readily oxidized and cannot be beneficiated by mere roasting. As a result ores whose manganese is contained largely in rhodonite are not commonly regarded as a practical source of manganese.

The manganese content of the minerals found in western Utah may be indicated as follows:

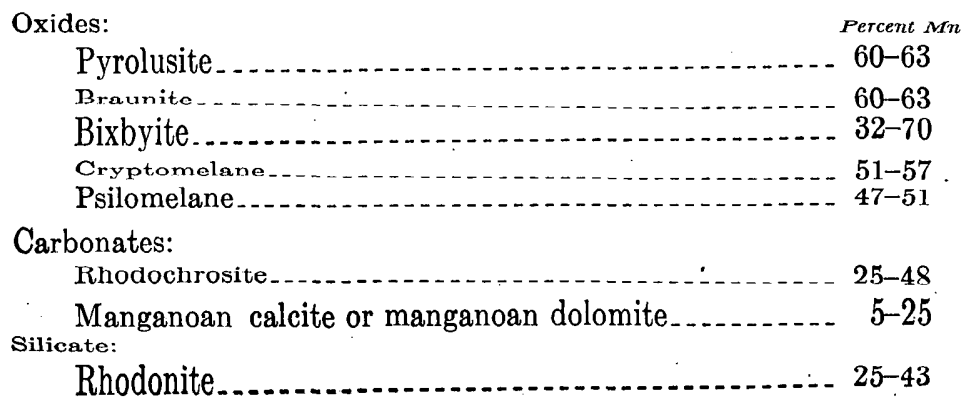

\section{OXIDATION AND ENRICHMENT}

More than 90 percent of the manganese ore shipped from western Utah was derived from primary manganese carbonate or silicate. Only a small part of this material would have been marketable had 
it not been converted to oxides. Thus the commercial value of the ore has been determined in large part by the effects of oxidation and by the enrichment that accompanied it.

The depth of oxidation is highly variable, even within a small area. In the Detroit district, the largest producer in the State, oxidation is known to extend to a depth of at least 200 feet, although large bodies of primary ore are preserved at much shallower depths. In the Tintic district, the second-largest producer, manganese oxides extend to a depth of at least 1,000 feet (Tintic Standard mine). Here remnants of primary ore are unknown.

In general, oxidation extends from the surface of the ground to the level of the water table, because the oxygen present in the aerated zone readily converts the unstable manganese minerals to oxides. Occurrence of remnants of primary ore above the general water table is usually controlled by structural traps that have caused local accumulations of ground water. In these areas, and below the general water table, the primary minerals are protected from oxidation.

The degree of enrichment of the oxide ore over the primary material is lighly variable and is influenced by the stability of the primary minerals, the nature of the gangue, the volume and acidity of the meteoric water, and many other factors. Rhodochrosite, for example, is much more readily oxidized than rhodonite. A soluble gangue mineral may be removed by leaching, thereby increasing the concentration of the manganese oxides, which are relatively insoluble. The arid or semiarid climate of parts of western Utah is conducive to deep oxidation and marked enrichment.

\section{CLASSIFICATION AND ORIGIN OF THE DEPOSITS}

\section{GENERAL DISCUSSION}

The manganese deposits of western Utah can readily be divided into two groups according to their manner of deposition. The first group consists of syngenetic deposits, in which the manganese was originally deposited with, and at the same time as, the enclosing rocks. This group includes bedded deposits commonly intercalated with sedimentary rocks and deposits interbedded with tufa formed by chemical precipitation from thermal springs. Only a few of the deposits of this group in western Utah are of commercial importance.

The second group consists of epigenetic deposits, in which the manganese was introduced into the enclosing rocks after their formation. This group includes hydrothermal vein and replacement deposits whose oxidized zones have yielded most of the manganese ore produced in western Utah. It also includes numerous small deposits of oxides that are too poorly exposed to permit the source of the manganese to be determined.

$945346-51-3$ 
An understanding of the factors governing the classification here given is of value to the mine operator and prospector as well as to the geologist. It may enable them to anticipate in advance the change from oxide ore to primary ore at the water table and to plan development and operation with this change in view.

Genetic classification of the manganese deposits of western.Utah

Syngenetic deposits:

Bedded deposits:

Washington County:

Black Beauty No. 1.

Wallace.

Iron County:

Blackhawk and Joe Louis (?).

Black Jack, or Gregory (?).

Wasatch County:

Grey Hawk.

East Star No. 1.

Spring deposits:

Juab County:

Abraham Hot Spring.

Salt Lake County:

Evans lime quarry.

Epigenetic deposits:

Oxidized hydrothermal deposits:

Beaver County:

Susie Q.

Big Mapie.

Cache County:

Blacksmith Fork.

Iron County:

Clove.

Modena.

Juab County:

Detroit district.

Orme.

Black Ledge (?).

Rich County:

Lakeview.

Sait Lake County:

Michigan-Utah.

Summit County:

Park City district (Silver King and Ontario mines).

Tooele County:

Benmore and Sharp.

Erickson district.

Ophir Hill.

Utah County:

Tintic district.

Trotter.

Spalding.

Queen of the West. 
Epigenetic deposits-Continued

Deposits of oxides of undetermined origin:

Beaver County:

Black Rock, or Shotwell.

Spor.

Black Jack, or Skougard.

Garfield County:

Fullmer.

Hawkins.

Unnamed (northwest of Panguitch).

Iron County:

Lucky Joe.

Taylor.

Juab County:

Black Jack, or Kendall-Duvall.

Piute County:

Blue Miami Moon.

Blackbird.

Dry Canyon.

Gilbert.

Sevier County:

Noonday.

Georgia.

Utah County:

Wildcat.

Weber County:

Payday.

Deposits for which geologic data are scant:

Beaver County:

Steelville.

Salt Lake County:

Manganese Lode.

Sevier County:

Jumbo.

\section{S YNGENETIC DEPOSITS}

BEDDED DEPOSITS

Manganese deposits are found in Utah interbedded with sedimentary rocks of several different ages. Baker, Duncan, and Hunt (in preparation) have described in detail the deposits in southeastern Utah that are associated with the Morrison and Summerville formations (Jurassic) and the Chinle formation (Triassic). In the southwestern part of the State, deposits have been found in these formations and also in the lower part of the Carmel formation.

The only syngenetic deposit in western Utah that was examined by the author is the Black Beauty No. 1 claim in Washington County. Here manganese oxides occur at a horizon about 50 feet above the base of the Carmel formation in red and white silty clay and shale. Lenticular beds and irregular masses of gypsum crop out both above and below the manganiferous zone. The manganese oxides occur in 
lenticular masses a few feet long and as much as 5 inches thick and are visible along the strike for several hundred feet. In the single specimen that was studied in the laboratory, the manganese oxides are in bands $1 / 25$ to $1 / 2$ inch thick interlayered with bands of pinkishbrown celestite $1 / 8$ to 1 inch thick. The celestite $\left(\mathrm{SrSO}_{4}\right)$ was not identified in the field, and it is not known whether this mineral occurs throughout the deposit. The banding of the manganese oxides and celestite and the restriction of the manganiferous lenses to a single stratigraphic horizon both suggest that the manganese and celestite were deposited together with the enclosing gypsiferous sediments.

In all these bedded occurrences the manganese oxides are concentrated in layers, form irregular nodules and pellets, or fill the interstices between- the grains of the enclosing rock. Commonly, the oxides can be traced along the strike for considerable distances, or they may appear in the same horizons at isolated points separated by barren intervals. These broad relations, combined with the lack of feeding fissures or a fixed relation to topography, suggest that the manganese was originally deposited with the sediments. Direct evidence of this is often lacking, however, and the details of occurrence commonly indicate that the manganese has been more or less redistributed by ground water. None of the bedded deposits in Utah has been followed far enough in from the outcrop to indicate whether or not the oxides observed on the surface are derived from other minerals. Although the largest manganese deposits in the world are of the bedded type, none of the bedded deposits in western Utah is known to have yielded ore in commercial quantities.

\section{SPRING DEPOSITS}

Deposits of manganese formed by precipitation from springs are comparatively rare. However, manganese has been shipped from two such deposits in Utah. The largest and best known, the Abraham Hot Spring deposit in Juab County northwest of Delta, has been described by Callaghan and Thomas (1939). They conclude that the spring probably derives its heat from a magmatic source, but they failed to find conclusive evidence that any of the minerals being deposited were of magmatic origin. (See p. 25.)

Another deposit believed to have been formed by springs is the one at the Evans lime quarry in Salt Lake County (pp. 34-35). Here there is no longer any spring activity, and there is nothing to indicate whether the water was hot or cold. The manganese is associated with massive but well-bedded travertine that appears to form broad mounds, now mostly buried by terrace gravel of Lake Bonneville. The most common mineral is wad, which occurs in irregular masses veining or replacing the travertine. Locally within the wad there are nodules or 
veinlets of high-grade pyrolusite. The ultimate source of the manganese found in this deposit is unknown.

\section{EPIGENETIC DEPOSITS}

\section{OXIDIZED HYDROTHERMAL DEPOSITS}

The widespread occurrence of manganese in hydrothermal ore deposits of the western United States was pointed out by Hewett and Pardee (1933), and more recent work has shown that deposits of this type are even more widely distributed in Utah than they indicated. Manganese oxides associated with precious or base metals and obviously derived from rhodochrosite, rhodonite, or manganiferous carbonates of hydrothermal origin have been shipped from the Erickson, Tintic, Detroit, Ophir (Ophir Hill mine), Little Cottonwood (Michigan-Utah mine), and Columbia (Benmore and Sharp mines) mining districts. Such shipments have constituted more than 90 percent of. the manganese ore produced in western Utah.

The manganese minerals commoniy occur in well-defined ore bodies localized by bedding or fault fissures and occasionally overlying or adjoining bodies of lead, zinc, gold, or silver ore. The most productive and best-exposed of these deposits are the Staats and Pratt mines in the Detroit district. These are bedding-replacement deposits formed at the intersection of certain dolomitic beds with premineral fissures. The manganese oxides that crop out at the surface have been followed downward to reveal the primary manganese carbonate, with which are associated small amounts of pyrite, galena, sphalerite, gold, and silver. These same minerals extend downward from the larger deposits along premineral faults and fractures, whose identity as feeding fissures is thereby indicated.

In the Erickson district (pp. 39-44), rhodonite and rhodochrosite, associated with galena, sphalerite, and a little chalcopyrite, are encountered in the Black Jack and Black Rock groups of claims at depths of 50 feet or less. In the Bingham district, Boutwell (1905, pp. 160-161) indicates that rhodochrosite is not uncommonly present as a gangue mineral in the lead, zinc, and silver veins. Its occurrence there in the central part of crustified veins suggests that it was introduced during the late stages of mineralization, following the deposition of most of the precious and base metals. This relation appears to be characteristic of base-metal veins containing rhodochrosite, but it is less well demonstrated in Utah than elsewhere (Hewett and Pardee, 1933, pp. 673-674; Goddard, 1940, pl. 27).

Pyrolusite is the most abundant oxide mineral derived from oxidation of these deposits. Psilomelane-type minerals are commonly present, but seldom in large quantity. 


\section{DEPOSITS OF OXIDES OF UNDETERMINED ORIGIN}

Many small epigenetic deposits of manganese oxides are insufficiently exposed to reveal the source of the manganese. Most of them are isolated veins or impregnations resembling deposits of hydrothermal origin. Others are irregular veins or impregnations that show no associated hydrothermal alteration and that appear to narrow downward. Such deposits may have been formed by laterally moving ground water.

The Payday mine, east of Ogden (pp. 57-58), is the best example of this type of deposit. Here manganese oxides occur in the basal conglomerate of the flat-lying Almy formation of early Eocene age, which consists of rounded boulders as much as 2 feet in diameter loosely cemented by sand, gravel, and a little clay. The conglomerate rests on a generally smooth but locally irregular erosion surface that truncates the bedding of Cambrian limestone at an angle of $30^{\circ}$ to $40^{\circ}$. The ore, a mixture of psilomelane and coarsely crystalline pyrolusite, occurs as cement between and around the boulders of the conglomerate and as irregular concretionary masses in the clayey zones.

In the vicinity of the mine, Causey Creek and the Ogden River have cut through the Almy formation to a depth of 200 feet or more, and the principal exposure of ore is on a steep, narrow point between the two streams. It is reported, however, that the manganese oxides also occur in the base of the conglomerate on the opposite sides of both Causey Creek and the Ogden River. Clearly, the manganese was deposited before the canyons were cut to their present depth.

Although a small quantity of wad was found along bedding planes and fractures in the limestone beneath the conglomerate, there is no suggestion of feeding fissures that cut the bedrock, and nowhere has ore been exposed more than a few feet below the contact. Thus there is nothing to indicate, unequivocally, the source of the manganese.

\section{RESERVES AND FUTURE OUTLOOK}

The known manganese deposits of western Utah are estimated to contain reserves of more than 360,000 long tons, of which 50,000 to 60,000 long tons is believed to be profitably recoverable under present conditions. Of more than 30 mines and prospects considered, less than 10 are sufficiently developed to permit evaluation of measured and indicated ore. The others are partly or not at all developed, and their reserves have been inferred from their geologic character and environment.

The reserves, summarized in table 4, include both oxides and carbonate wherever the latter contains more than 10 percent manganese and occurs in bodies large enough to be minable. About one-third of the total reserve is carbonate ore. 
TÁBLE 4.-Estimated reserves of manganese ore in western Utah, in long tons

\begin{tabular}{|c|c|c|c|c|c|}
\hline \multirow{2}{*}{ Type of reserve } & \multicolumn{4}{|c|}{ Percent Mn } & \multirow{2}{*}{ Total } \\
\hline & $10-20$ & $20-30$ & $30-40$ & $\begin{array}{l}\text { More than } \\
40\end{array}$ & \\
\hline $\begin{array}{l}\text { Measured } 1 \\
\text { Indicated }{ }^{2} \\
\text { Inferred }{ }^{3} \\
\text { Total }\end{array}$ & $\begin{array}{r}26,000 \\
140,000 \\
150,000 \\
316,000\end{array}$ & $\begin{array}{l}11,000 \\
10,000 \\
25,000 \\
46,000\end{array}$ & $\begin{array}{r}100 \\
500 \\
700 \\
1,300\end{array}$ & $\begin{array}{r}0 \\
0 \\
200 \\
200\end{array}$ & $\begin{array}{r}37,000 \\
150,500 \\
175,900 \\
363,500\end{array}$ \\
\hline
\end{tabular}

1 Measured reserves are calculated from surface e xposures, trenches, or underground workings and include blocks whose size and grado are well established.

2 Indicated reserves are estimated from surface exposures, workings, or drill holes but are subject to larger errors in both quantity and grade.

${ }^{3}$ Inferred reserves may be poorly or not at all exposed and are estimated on the basis of geologic data.

The grade of material that is profitably recoverable at any time depends on economic rather than geologic factors. On the basis of recent wartime experience, most of the material containing 10 to 20 percent manganese is submarginal even under high prices. Moreover, at least half the material containing 20 to 30 percent manganese is in bodies too small or too remote to be minable except during such periods of unusually high prices. Consequently, about 25,000 long tons averaging 20 to 30 percent manganese is probably a reasonable estimate of the actual known reserves of "ore." In terms of longrange outlook, new discoveries or higher prices might double this figure.

Although most of the ore in western Utah is too low, in grade to compete in Eastern markets with high-grade foreign ore, probably it will continue to find, as it has found in the past, a market at local smelters for the production of high-manganese pig iron.

The outlook for new discoveries of manganese ore in western Utah is not entirely discouraging, in spite of the fact that all the manganeseproducing districts known today were discovered before 1920. As indicated in figure 2, discoveries of ore within districts already known are largely dependent on price, market, and other factors directly stimulating exploration. An example of this dependence is the discovery in 1941 of the Pratt ore body in the Detroit district. This was a body, entirely concealed, that was encountered in the course of diamond drilling conducted by the U. S. Bureau of Mines and the U. S. Geological Survey. This one ore body contained more ore than had previously been produced by the entire district.

There is no reason to doubt the existence of other undiscovered ore bodies. However, the areas most likely to yield them are relatively small and have been thoroughly prospected on the surface. Continued exploration, combined with the detailed study of structural control, will probably reveal additional ore, but the cost will be an increasingly large percentage of the value of the ore recovered. It 
DISCOVERIES IN

PRICE IN DOLLARS

LONG TONS

PER LONG TON

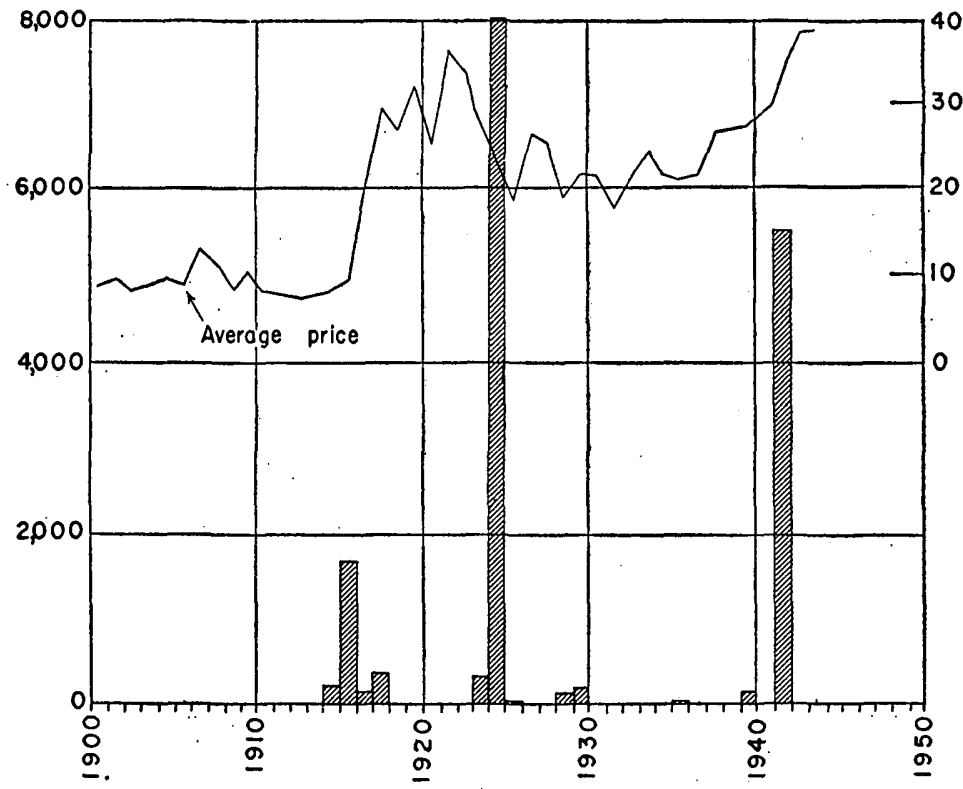

Figdre 2.-Chart showing discoveries and price of manganese ore in western Utah, 1914-42. Data from U. S. Bureau of Mines Minerals Yearbook. Includes manganiferous ore and ferruginous manganese ore. Where the actual discovery date of a particular mine or ore body is unknown, the ore is credited to the year preceding that in which it was first produced.

seems doubtful that production of manganese ore in western Utah during the next 50 years will equal that already attained since 1900 .

\section{DESCRIPTIONS OF INDIVIDUAL DEPOSITS}

In the following pages the manganese mines and mining districts of western Utah are described individually. They are arranged by counties, which are listed in alphabetical order. However, the most important districts-Detroit, Tintic, and Erickson-lie on the boundary between two counties and have deposits in both. All the districts so situated are described under joint headings. For example, the Detroit district is listed under Juab and Millard Counties, the Tintic district under Utah and Juab Counties.

The report on each deposit includes such data as alternative names, location, ownership, lessees, and development. Production, if any, is summarized on an annual basis in the first few paragraphs of each report. The name of the geologist who wrote the original report, or the published source from which the information has been taken, also is given. Those deposits that have not been visited by members of the Geological Survey are so indicated. The information concerning 
many of these deposits was obtained by engineers and chemists of the Bureau of Mines and is included in this compilation with the permission of the Director of the Bureau of Mines.

\section{BEAVER COUNTY}

SUSIE Q CLAIMS

The Susie Q group of seven claims is 0.85 mile north of the county road from Milford to the Cougar Spar mine area and 5 miles west of the Burn Knoll Reservoir. It is on the north edge of sec. 16, T. $30 \mathrm{~S}$, R. $14 \mathrm{~W}$. The property, originally called the Iron Lily, is owned by Glen Barnes, of Milford, Utah, and R. L. Malstrom; it was leased in 1943 to J. M. Clawson. Some ore is reported to have been shipped to Frisco, Utah, for use as flux. The road ends about 100 feet west of a short adit on the Susie $Q$ No. 1 claim. Six tons of ore, reported to contain 40 to 45 percent manganese and shipped from this opening to the Metals Reserve Co. stockpile in Delta in 1943, constitute the only recent production. This group of claims was examined by the writer in April 1946.

The ore removed from the Susie $Q$ deposits formed an irregular body at the intersection of two nearly vertical faults, one striking nearly east, the other nearly north. The wall rock is thin-bedded limestone that has been locally brecciated. The ore remaining appears to be comparable in grade to that of the shipments, but the quality appears to be very small:

The principal openings are on the Susie Q No. 1 claim about 600 feet southeast of the end of the road. Here is an open pit 20 feet in diameter at the top of a caved shaft that presumably was dug late in the 1800's. A new shaft 30 feet south of the original pit was sunk by lessees in 1940. These workings lie on a nearly vertical fault zone that strikes $\mathrm{N} .25^{\circ} \mathrm{W}$. The zone passes through the west edge of the pit but is covered by broken rock. In the new shaft it is 5 to 8 feet wide with a rather prominent shear down the middle. East of this fault surface, the zone is filled with sheared talcose material in which dendritic masses of manganese oxide have developed. The average grade of this material is probably less than 5 percent manganese. West of the fault surface, the talcose material is iron-stained and contains only traces of manganese.

The walls of the main pit consist of brecciated and silicified limestone heavily stained by manganese and iron oxides and cut by veins of coarsely crystalline calcite. The mineralized area in the east edge of the pit appears to follow the bedding of the limestone country rock, which strikes $\mathrm{N} .70^{\circ}-75^{\circ} \mathrm{E}$. and dips $20^{\circ}$ to $25^{\circ} \mathrm{S}$. The distribution of manganese oxides is irregular, and considerable areas are entirely barren. A 3 -foot sample across the best part of the face 
would probably average 15 to 30 percent manganese. The average grade, however, is probably 10 to 20 percent manganese.

The hand-sorted ore from the open pit consists of clinkery masses of iron and manganese oxides mixed with calcite. In some specimens the manganese oxide and calcite are intimately intergrown; in others the calcite is leached out, leaving cellular masses of oxides. Elsewhere the manganese occurs in veins, spongy masses, or layered crusts. Rarely, prismatic radiating crystals can be found in thin veins. Pyrolusite was the only mineral recognized.

Five or ten tons of material have been stockpiled on the west edge of the large open pit. A 2-ton sample of this rock was taken by the Bureau of Mines for metallurgical testing and was found by their analysis to contain 8.5 percent $\mathrm{Mn}, 16.4$ percent $\mathrm{SiO}_{2}, 6.5$ percent $\mathrm{CaO}, 26.5$ percent $\mathrm{Fe}$, and 11.3 percent $\mathrm{Al}_{2} \mathrm{O}_{3}$.

\section{BLACK ROCK (SHOTWELL) DEPOSIT}

The Black Rock, or Shotwell, deposit is in the S1/2 T. $28 \mathrm{~S}$., R. $6 \mathrm{~W}$., on the west flank of the Tushar Range, about 10 miles northeast of Beaver, Utah. It is owned by J. E. Shotwell, of Beaver. The deposit was examined by A. E. Granger in February 1943. It consists of narrow veins and irregular masses of manganese that developed along faults in an intrusive rock, probably rhyolite porphyry. The veins exposed are a few feet long and a foot or less in thickness. The irregular bodies are usually less than 2 feet in diameter.

Much of the manganese oxide is so intimately mixed with silica that it can be separated only by metallurgical treatment; only a small amount of high-grade ore is available. Ore stockpiled on the property assayed 28 percent; however, the faces of the workings assayed only 5 to 18 percent.

\section{BLACK JACK (SKOUGARD) CLAIMS}

The Black Jack, or Skougard, group of three claims is in or near sec. 36 , T. 30 S., R. 15 W., on the east edge of the Blue Mountains, north of Lund, in the extreme southern part of Beaver County. It is owned by Horace and Don Skougard and Milton C. Morton. There has been no production. The deposit was examined by engineers of the U. S. Bureau of Mines in 1946. They reported to the author that the manganese oxides occur in irregular narrow veinlets cutting limestone near its contact with a mass of quartzite(?). The limestone strikes west and dips $20^{\circ}$ to $60^{\circ} \mathrm{S}$. The quartzite, also described as a "quartzite dike," is reported to strike north and dip $80^{\circ} \mathrm{W}$.

The grade of the ore is reported to range from 6 to 13 percent manganese; the ore occurs in such small veinlets that, according to the owners, it cannot be successfully hand-sorted. 
The Steelville prospect is in T. 27 S., R. 17 W., on the east edge of the Needle. Range, across White Sage Valley from the Wahwah mine. It is owned by A. G. James and was leased early in 1941 to W. W. Clays, C. S. Smith, J. Berman, and G. O. Smith and in December 1943 to Emile Pemental.

The deposit was examined in February 1941 by an engineer of the U. S. Bureau of Mines. Manganese oxides are reported to occur as flat-lying pods. They are described variously by W. H. King, of the Bureau, as "blanket veins * * * replacements in limestone" and as being "interbedded with playa deposits. Samples of the material are reported to range in grade from 10.47 to 31.2 percent manganese. An analysis of a 2-ton sample taken by the Bureau of Mines for metallurgical testing showed 28.8 percent $\mathrm{Mn}, 25.6$ percent $\mathrm{SiO}_{2}, 7.3$ percent $\mathrm{CaO}, 1.3$ percent $\mathrm{Fe}$, and 0.8 percent $\mathrm{P}$.

\section{SPOR PROPERTY}

The Spor property is in low hills on the east edge of the Needle Range, about 45 miles west of Milford. It is owned by George P. Spor and Chad Spor. It is reached by taking Highway 21 west from Milford for 35 miles, then turning left across White Sage Valley for 19 miles. However, the desert roads branch so frequently that it is impossible to find the property without a guide.

The deposit was examined by J. A. Straczek in June 1941. The country rock, dark-gray limestone interbedded with shale, strikes N. $10^{\circ}-30^{\circ} \mathrm{E}$. and dips $20^{\circ} \mathrm{SE}$. Manganese oxides occur as irregular masses, apparently. on the hanging wall of a bed of shale. The mineralized zone is as much as 3 feet thick and is reported by the owners to average 30 percent manganese and 20 percent silica. The mineralization may be controlled by faulting. A stocklike body of rhyolite porphyry(?) crops out about 300 feet east and northeast of the best exposures.

\section{BIG MAPLE AREA}

It has been stated that manganese oxides and calcite occur together in veins in the Big Maple area, T. 30 S., R. 9 W., 5 miles southeast of Minersville. This occurrence was reported in a letter from the owners, Alex H. Rollo, Dr. E. Smith, and George Smith, dated September 26, 1918.

\section{CACHE COUNTY}

BLACKSMITH FORK AREA

It is reported that manganese oxides occur as "high grade boulders in a deep fissure" at Pig Hole Hollow, left fork of Blacksmith Fork, 
15 miles east of Hyrum (T. 11 N., R. 3 E.). This information was given in letters from I. L. Neilsen, March 1, 1918, and W. W. Maugham, October 5, 1918.

\section{GARFIELD COUNTY}

FULLMER PROSPECT

A manganese prospect owned by John Fullmer and Sam Spencer is in the center of T. 35 S., R. 1 E., on the rugged Table Cliff Plateau about 10 miles west of Escalante. It was examined by M. E. Willard in August 1942. The manganese occurs as cement in a coarse conglomerate 15 feet thick that crops out on both sides of a very narrow ridge. The conglomerate rests on coarse barren sandstone and is overlain by gray limestone.

The manganese oxides may constitute as much as 20 to 25 percent of the conglomerate, but most of the material is much lower in grade. Mineralization is evident for a distance of about 100 feet along the ridge.

This deposit may be supergene or syngenetic, but the origin is not discussed in the original report.

\section{HAWKINS CLAIMS}

The Hawkins claims are in T. 32 S., R. 5 W., on the east side of the Tushar Range about 15 miles north of Panguitch. They are about half a mile from the end of a little-used wood road that leaves Highway 89 at a point 14 miles north of Panguitch. The country rocks are Tertiary volcanics interbedded with sandstone and conglomeratic sandstone; they strike east and dip south. The deposits are owned by Jay Proctor and Zera Church and were examined by A. E. Granger in October 1943.

Manganese occurs as local concentrations in the sandstone at places where ground water once issued as springs. Picked samples of this material are reported to assay as high as 30 percent manganese. There is relatively little such material available, however, and probably the average concentration contains less than 15 percent manganese.

\section{UNNAMED PROSPECT}

A second manganese prospect northwest of Panguitch has been described by Crawford and Buranek (1942). It is reportedly situated about 15 miles north of Panguitch, Utah, and about 3 miles west of U. S. Highway 89, from which it is reached by an old wood road leading westward through the low, piñon-covered mountains toward Dog Valley. The deposits consist of manganese dioxide cementing a series of shear zones and porous, bedded, volcanic sands. The manganese dioxide cement forms small, pealike, nodular concretions 
which in some cases are aggregated into massive manganese ore almost wholly replacing local areas in the country rock.

The deposit is believed to have formed by precipitation from ground water where springs emerged. The manganese presumably was dissolved by meteoric water from overlying or adjacent beds.

\section{IRON COUNTY}

\section{BLACK JACK (GREGORY) CLAIMS}

The Black Jack claims, owned by Cleve Gregory, are in the NW1/4 sèc. 11, T. 36 S., R. 15 W., three-quarters of a mile north of the Cedar City-Newcastle road and 3 miles east of Newcastle. The property was examined by the writer in April 1946. The manganese occurs in a lenticular bed of sandy limestone that is part of the Claron limestone, presumably of Eocene age. The bed crops out on the southeast slope of a low ridge and forms a prominent dark outcrop visible from the road. At the discovery monument the bed is 10 to 12 feet thick, strikes north, and dips $45^{\circ}-50^{\circ} \mathrm{W}$., but up the ridge the strike swings to northeast and the dip flattens. At the extreme north end of the outcrop, the manganiferous bed is only 1 to 2 feet thick and is off'set to the west by several small faults.

The manganiferous bed is underlain by red or pink tuffaceous sandstone that locally contains numerous fragments of volcanic rock. Immediately above the manganiferous bed is a zone of white or greenish altered dacite or rhyolite.

The lens of limestone is more or less blackened with manganese oxides over most of its length; however, its average grade is probably less than 5 percent manganese. Near the discovery monument there is considerable coarsely crystalline calcite that becomes very dark when weathered. It is usually light-colored beneath the surface, however, and probably contains only small amounts of manganese.

Because of the extremely low grade of the ore, it does not appear probable that the deposit can be worked profitably.

\section{CLOVE PROSPECT}

A manganese prospect owned by Ivor Clove, of Enterprise, Utah, is in the $\mathrm{SE}_{1 / 4}^{1 / 4}$ sec. 2 , T. $36 \mathrm{~S}$., R. $17 \mathrm{~W}$., about three-quarters of a mile S. $60^{\circ}$ W. of the abandoned Silver Dollar mine north of Enterprise. The prospect was examined by the writer in. April 1946. Several pits and a 30- to 40 -foot shaft have been sunk on veins or breccia zones cutting the rhyolite country rock. The vein filling is calcite and chalcedony that are heavily stained by iron and a little manganese oxide. The veins observed dip steeply and strike $\mathrm{N}$. $40^{\circ} \mathrm{W}$. The prospect does not appear to be a potential source of manganese. 
The Blackhawk and Joe Louis claims, owned by E. Duffin and Woods Parishont of Cedar City, Utah, are near the west edge of T. 36 S., R. 9 W., on the edge of the Markagunt Plateau, a mile north of Highway 14 and 13 to 14 miles by road east of Cedar City. They were examined by engineers of the Bureau of Mines, who report that a 9-foot adit has been sunk on a manganiferous zone 18 inches thick which crops out along the edge of a cliff for 150 feet. The material in places is reported to contain about 5 percent manganese.

\section{LUCKY JOE CLAIM}

The Lucky Joe claim, owned by J. Ross Harrison, is situated on the north edge of T. 36 S., R. $14 \mathrm{~W}$. It lies on the west side of Silver Peak Mountain, 6 miles northwest of Iron Mountain. It was examined by engineers of the Bureau of Mines, who report that a manganiferous zone striking S. $20^{\circ} \mathrm{E}$. is 6 feet wide and crops out for 150 feet. The wall rock is metamorphic limestone. A 6 -foot sample of the zone taken by the Bureau of Mines for metallurgical testing contained 2.3 percent $\mathrm{Mn}, 7.1$ percent $\mathrm{SiO}_{2}, 47.8$ percent $\mathrm{CaO}$, and 0.16 percent $\mathrm{P}$.

\section{TAYLOR PROSPECT}

A prospect owned by the Taylor brothers and associates is situated on the Knell ranch about a quarter of a mile east of Newcastle in the E $1 / 2$ sec. 16 , T. 36 S., R. 15 W. It was examined by engineers of the Bureau of Mines, who report that manganese occurs in southeaststriking veinlets in red rhyolite. The average grade of the material, however, is reported to be only 1 to 2 percent manganese.

\section{MODENA LOCALITY}

Manganese and iron oxides are reported by Harder (1910, p. 157) to occur near Modena, where they were observed with calcite in decomposed limestone on the footwall of a dike. Silver, gold, and lead also are reported to occur.

\section{UN NAMED PROSPECT}

Local residents report that a manganese prospect, owned by Sam Bill, is located south of the highway between Cedar City and Parowan.

\section{JUAB COUNTY}

\section{ABRAHAM HOT SPRING DEPOSIT}

The Abraham Hot Spring is at the east edge of a low lava plateau in the $\mathrm{E} 1 / 2$ sec. 10 , T. 14 S., R. 8 W., about 19 miles northwest of Delta, Utah. The water issues from a low mound about 1,600 feet in diameter and about 15 feet above the gently sloping plain of the Sevier Desert. In 1929 and 1930 it was known as the Iron King 
mine and was leased to Fred Staats, who shipped 714 long tons of ore containing 20.8 percent manganese. The material was obtained from numerous pits and trenches all less than 6 feet deep. The manganese occurs in distinct and apparently lenticular layers interbedded with nearly barren calcareous tufa. There is little or no manganese being deposited at present, and the uppermost layers of the mound are composed of clay, iron oxide, and porous calcite.

In 1935 the spring was estimated (Callaghan and Thomas, 1939, p. 905) to be discharging more than 1,200 gallons per minute of water that ranged in temperature from $110^{\circ}$ to $182^{\circ} \mathrm{F}$. Five samples of water that were analyzed showed the range in composition indicated in table 5 .

TABLE 5.-Range in composition of samples of water from Abraham Hot Spring, Juab County, Utah

\begin{tabular}{|c|c|c|c|c|c|}
\hline & \multicolumn{2}{|c|}{ Parts per million } & \multirow[t]{2}{*}{. } & \multicolumn{2}{|c|}{ Parts per million } \\
\hline & Minimum & Maximum & & Minimum & Maximum \\
\hline $\begin{array}{l}\mathrm{SiO}_{2} \\
\mathrm{Mn} \\
\mathrm{Ca} \\
\mathrm{Mg}\end{array}$ & $\begin{array}{c}60 \\
350 \\
52\end{array}$ & $\begin{array}{l}68 \\
1.20 \\
362 \\
56\end{array}$ & $\begin{array}{l}\mathrm{Na}+\mathrm{K} \\
\mathrm{SO}_{4} \\
\mathrm{Cl}\end{array}$ & $\begin{array}{r}841 \\
702 \\
1,460\end{array}$ & $\begin{array}{r}883 \\
726 \\
\cdot \quad 1,535\end{array}$ \\
\hline
\end{tabular}

Total dissolved solids: 3,796 to 4,015 parts per million.

Callaghan and Thomas point out that the observed quantity of manganese is less than the average reported for river water in the temperate zone and that otherwise the composition closely resembles that of many of the ordinary wells in the Sevier Desert. None of the elements present necessarily indicates an immediate igneous source, and Callaghan and Thomas $(1939$, p. 917) therefore conclude that "the lack of demonstrable volcanic materials in the discharge of the Abraham Hot Spring makes it impossible to prove a magmatic connection, even though the abnormal geothermal gradient and the presence of recent extinct craters points to a magmatic heat supply." They regard the water "as surface or meteoric waters that percolate downward to sufficiently great depth to attain a high temperature, and return to the surface through a convenient conduit provided by a fracture or a volcanic pipe."

Relatively little of the material remaining at the mound contains more than 15 percent manganese, and it is unlikely that it constitutes a potential source of manganese.

\section{BLACK JACK (NEILSON) CLAIMS}

The Black Jack claims that belong to the Neilson brothers; William C. Overson, and F. D. Dains are in secs. 33 and 34, T. 14 S., R. 3 W., and secs. 3 and 4 , T. 15 S., R. 3 W., about three-quarters of a mile 
south of a lime quarry in the Sevier River canyon, 5 miles east of Leamington. The claims were examined by engineers of the U. S. Bureau of Mines, who report that manganiferous iron oxides occur at several borizons in limestone and conglomerate. Two hand samples contained 0.6 percent manganese and 2.7 percent manganese. There is no record that the material has been shipped for its manganese content.

\section{BLACK JACK (KENDALL-DUVALL) CLAIMS}

The Black Jack claims owned by Henry Kendall and Ralph Duvall were examined by engineers of the U.S. Bureau of Mines, who report that they are on the top of a ridge, 2 miles east of Highway 28, at a point 13 miles south of Levan. The ore is described as braunite and a little psilomelane with a gangue of quartz and chalcedony. It occurs in veins cutting sandstone. Two samples of the ore were taken by the Bureau of Mines for metallurgical tests (table 6).

TABLe 6.-Assay by. U. S. Bureau of Mines of metallurgical sample from Black Jack (Kendall-Duvall) claims, Juab County, Utah

\begin{tabular}{|c|c|c|c|c|c|}
\hline . & $\begin{array}{l}\text { Representa- } \\
\text { tive vein } \\
\text { material } \\
\text { (percent) }\end{array}$ & $\begin{array}{l}\text { Impregnated } \\
\text { sandstone } \\
\text { (percent) }\end{array}$ & & $\begin{array}{l}\text { Representa- } \\
\text { tive vein } \\
\text { material } \\
\text { (percent) }\end{array}$ & $\begin{array}{l}\text { Impregnated } \\
\text { sandstone } \\
\text { (percent) }\end{array}$ \\
\hline $\begin{array}{l}\mathrm{Mn} \\
\mathrm{Fe} \\
\mathrm{SiO}_{2} \\
\mathrm{CaO}\end{array}$ & $\begin{array}{r}9.3 \\
.7 \\
34.1 \\
22.6\end{array}$ & $\begin{array}{r}6.4 \\
3.6 \\
40.8 \\
10.2\end{array}$ & $\begin{array}{l}\mathrm{Al}_{2} \mathrm{O}_{3} \ldots \ldots \\
\mathrm{Ba} \\
\mathrm{P}\end{array}$ & $\begin{array}{l}2.3 \\
2.7 \\
.009\end{array}$ & $\begin{array}{l}14.3 \\
.7 \\
.047\end{array}$ \\
\hline
\end{tabular}

\section{ORME PROPERTY}

The Orme property is in the SW $1 / 4$ sec. 32 , T. 16 S., R. 1 W., in a low range of hills on the east side of the Sevier Bridge Reservoir, 13 miles south of Levan. It is owned by W. G. Orme, T. W. Allred, and E. B. Sperry and was operated in 1938 by Fred Staats, who shipped 100 tons of ore. The property was examined by A. E. Granger in March 1943. Development consists of a short inclined shaft, an adit (caved), and several trenches.

The low hills are composed of interbedded conglomerate, volcanic breccia, and rhyolitic flows, which strike north and dip to the west. These rocks are cut by a series of nearly vertical faults that also strike north. Manganese oxides occur in veins or pods along two and probably three of the faults. The ore minerals are psilomelane and pyrolusite. The gangue is coarsely crystalline calcite and opaline silica. The masses of manganese oxide range from a few inches to 3 feet in thickness and are several feet long. Exposures indicate that the veins are 1,000 to 1,500 feet long. 
The Black Ledge group of five claims, owned by J. E. and Jim McFarlane, is believed to be in sec. 28, T. 12 S., R. 2 E. It is at the extreme south end of the Wasatch Range, at an altitude of 6,000 feet. By road, it is 8 miles east of Nephi and 11/2 miles north of the Nebo junction. The property was examined by J. H. Wiese and G. L. Bell in September 1942. The claims cover the top of an andesite-capped knob and extend down the slope below it to a creek. The andesite is a single flow, 35 feet thick, intercalated with conglomerate that strikes approximately east and dips $10^{\circ}$ to $20^{\circ} \mathrm{N}$.

Veinlets containing manganese oxides, chalcedony, and a little barite fill a network of irregular fractures in the andesite and are concentrated in two northeastward-trending zones, each 30 feet wide and 100 feet long. Mineralized float from the andesite capping has covered the outcrop of the underlying conglomerate for several hundred feet down the slope, but the conglomerate itself is barren. Development consists of two small pits.

Although hand specimens of high-grade ore can be obtained, the average grade of the entire deposit appears to be 5 percent manganese or less. Two samples of parts of the vein, taken by the Bureau of Mines, contained 7.6 percent and 14.2 percent manganese. A specimen of massive chalcedony and pyrolusite assayed by the Bureau of Mines contained 30 percent manganese.

\section{TOPAZ MOUNTAIN LOCALITY}

An interesting occurrence of the manganese mineral bixbyite in the topaz-bearing rhyolite of Topaz Mountain has been described by Palache (1934) and by Pabst (1938). It is of no economic value.

\section{JUAB AND MILLARD COUNTIES}

\section{DETROIT DISTRICT}

The Detroit mining district is on the Juab-Millard County line, in the Drum Mountains, about 100 miles southwest of Salt Lake City and 30 miles northwest of Delta. The principal mines are the Staats and Pratt properties, which constitute the Black Boy group. They are located 1 to 3 miles southeast of the abandoned mining town of Joy. These deposits have produced almost two-thirds of the ore mined in Utah since 1900.

The unweathered manganese deposits of the Detroit mining district are epigenetic hydrothermal bedding replacements in which the manganese was originally deposited as rhodochrosite (Callaghan, 1938, p. 513). Part of the ore has been affected by. surface and ground water, and the resulting oxides have contributed most of the production. A total of 57,692 long tons of ore has been produced, of which 57,157 tons came from the Black Boy group.

945346-51-5 
The Drum Mountains are a structural unit, consisting of nearly homoclinal beds striking N. $30^{\circ} \mathrm{W}$. and dipping $30^{\circ} \mathrm{SW}$. All the rocks are apparently of Cambrian age and include 5,000 feet of quartzite overlain by an equal thickness of limestone and dolomite. The homocline is cut by numerous faults that strike northeast to east, nearly at right angles to the strike of the beds. Most of the faults have displacements of 100 feet or less. Small bodies of quartzmonzonite porphyry are exposed here and there along faults, and there are a few irregular stocklike bodies and sills.

The manganese deposits are formed near the intersection of major faults with certain dolomitic beds at the base of the calcareous rocks. The ore bodies that have resulted range from small ones only a few feet in diameter to others that are 500 feet long and 50 feet wide. The grade of some of the oxide ore is as high as 48 percent manganese, but the average of all the shipments is only 20 to 25 percent. Some of the carbonate ore contains as much as 40 percent manganese; most of it contains only 15 to 25 percent manganese.

\section{STAATS AND PRATT MINES (BLACK BOY GROUP)}

The Staats and Pratt mines comprise a large number of claims, bearing the name Black Boy, which have been known collectively as the Black Boy mine or group. They are in the SE1/4 sec. 25, T. 14 $\mathrm{S} ., \mathrm{R} 11 \mathrm{~W}$., in a canyon on the north slope of the Drum Mountains, about a mile southeast of the old mining settlement of Joy. Ownership is divided; some of the claims are owned by Fred Staats of Salt Lake City and the others by the Frank Pratt heirs. The principal workings of the two properties are about 700 feet apart, and during recent years they have been operated independently. For this reason, and for convenience in describing them, the two sets of workings are referred to here as the Staats and Pratt mines, although part of the so-called "Pratt mine" is actually owned by Staats. The recorded production is given in table 7 .

The Staats mine is mostly in the floor of the canyon above the tributary leading to the Ibex mine. The workings consist of several open pits, an adit with connecting stopes, a 200 -foot inclined shaft with adjoining stopes, and a 70 -foot vertical shaft.

Nearly all these workings are in the bottom of the wash, where the bedrock is covered by 2 to 15 feet of alluvium. Consequently many of the structural features cannot be traced with certainty. The principal structural feature, however, is the branching Staats fault, a normal fault dipping $40^{\circ}$ to $70^{\circ} \mathrm{S}$. and striking nearly east. Most of the development is within a sliver-shaped block formed by a split in this fault. The principal primary manganese mineral is rhodochrosite, which has selectively replaced impure dolomite of two hori- 
TABLE 7.-Manganese-ore production, Staats and Pratt mines, Detroit district, Juab and Millard Counties, Utah

\begin{tabular}{|c|c|c|c|}
\hline Year & Shipper & $\begin{array}{l}\text { Production } \\
\text { (long tons) }\end{array}$ & $\begin{array}{l}\text { Grade (per- } \\
\text { cent Mn) }\end{array}$ \\
\hline 1925 & H. S. Joseph.. & 500 & \\
\hline 1927 & J. A. Owens. & 21 & 23.1 \\
\hline 1928 & Fred Staats........ & 286 & 24.5 \\
\hline $\begin{array}{l}1929 \\
1930\end{array}$ & Do Do & $\begin{array}{l}4,084 \\
7,828\end{array}$ & $\begin{array}{l}22 \\
22.6\end{array}$ \\
\hline & C. W. Jenkins... & 33 & \\
\hline 1935 & Fred Staats...... & 190 & 32 \\
\hline 1936 & $\begin{array}{r}\text { Do } \\
\text { Do. W. Jenkins. }\end{array}$ & $\begin{array}{l}1,635 \\
1,312 \\
420\end{array}$ & $\begin{array}{l}38 \\
32 \\
32.7\end{array}$ \\
\hline 1937 & 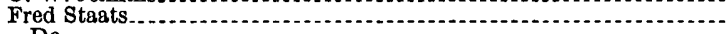 & 1,483 & 28.4 \\
\hline & C. W. Jenkins. & $\begin{array}{r}32 \\
1,600\end{array}$ & $\begin{array}{l}38.3 \\
32.9\end{array}$ \\
\hline 1939 & Fred Staats.... & 59 & 17 \\
\hline 1940 & $\begin{array}{l}\text { Do } \\
\text { Ward Leasing Co }\end{array}$ & $\begin{array}{r}30 \\
454\end{array}$ & $\begin{array}{l}37 \\
22.57\end{array}$ \\
\hline 1941 & Do. & 324 & 21.2 \\
\hline 1942 & $\begin{array}{l}\text { Fred Staats... } \\
\text { Ward Leasing } \mathrm{Co}^{-}\end{array}$ & $\begin{array}{r}246 \\
1,189\end{array}$ & $\begin{array}{l}30.8 \\
23.22\end{array}$ \\
\hline 1943 & Fred Staats..... & 6,781 & 30 \\
\hline & $\begin{array}{l}\text { Staats, Cornet, \& M } \\
\text { Ward Leasing Co... }\end{array}$ & $\begin{array}{r}2,621 \\
11,135\end{array}$ & $\begin{array}{r}.25 .61 \\
23.82\end{array}$ \\
\hline 1944 & Fred Staats. & 538 & 27.5 \\
\hline \multirow{4}{*}{1845} & $\begin{array}{l}\text { Staats, Cornet, \& } \\
\text { Ward Leasing Co }\end{array}$ & 491 & 25.12 \\
\hline & & 9,816 & 20.38 \\
\hline & Do.. & 4,234 & 29 \\
\hline & Total and average & 57,570 & 25.2 \\
\hline
\end{tabular}

zons. The lowest of these horizons, called dolomite $\mathrm{A}$, is $\mathrm{a}$ unit about 20 feet thick underlain by quartzite and overlain by 20 feet of shale and shaly quartzite. Above this shale zone is 85 feet of limestone (limestone B), at the base of which is a 2- to 8-foot dolomitic zone that also has been locally replaced. The extent of replacement within the beds is controlled by faults along which the mineralizing solutions moved. The separate ore bodies contain a few tons to as much as 50,000 tons each, and the grade ranges from 5 to 35 percent manganese.

Near the surface the rhodochrosite ore bodies have been partly oxidized, and most of the ore mined has consisted of this material. Relatively little such material remains. In 1941, however, diamond drilling by the U. S. Bureau of Mines proved the existence of a considerable tonnage of primary manganiferous carbonate averaging 10 to 20 percent manganese. This ore was found in downward extensions of the ore beds, west of the present workings.

The Pratt mine is on the north side of the valley about 700 feet northwest of the Staats property. Ore was exposed at the surface along the Pratt fault and was developed by an open-cut 300 feet long, 60 feet wide, and 20 feet deep. Later it was worked by underground methods through shaft 5 . A second ore body, discovered farther east along the same fault, was stoped from a second open-cut and adit and later from shaft 6 . The largest ore body in the property, 
the Pratt ore body, was discovered underground north of the Pratt fault by diamond drilling (King, 1947). It was worked through shaft 6 and a series of irregular sublevels and inclined shafts, and at the time the mine closed down it was largely worked out.

\section{GUY GROUP (BLACK JACK MINE)}

The Guy group, or the Black Jack mine, is in the $\mathrm{NE}^{1 / 4}$ sec. $7, \mathrm{~T}$. $15 \mathrm{~S} .$, R. $10 \mathrm{~W}$., about $2 \frac{3 / 4}{4}$ miles southeast of the Black Boy group. It was originally operated by H. S. Joseph in 1924 but is now owned by J. E. Dowd; during $1940-41$ it was leased to S. C. Trotter. The property was examined by J. S. Straczek and Ralph J. Roberts in 1941. Development consists of an open pit 150 feet long, 50 feet wide, and 20 feet deep and some short adits and trenches. Table 8 shows the known production.

TABLE 8.-Manganese-ore production, Guy group (Black Jack mine), Detroit district, Juab and Millard Counties, Utah

\begin{tabular}{|c|c|c|c|c|}
\hline Year & Shipper & Destination & $\begin{array}{l}\text { Ore shipped } \\
\text { (long tons) }\end{array}$ & $\underset{\text { (percent } \mathrm{Mn} \text { ) }}{\text { Grade }}$ \\
\hline \multirow[t]{2}{*}{$\begin{array}{l}1924 \\
1940 \\
1941 \\
1943 \\
1944\end{array}$} & $\begin{array}{l}\text { H. S. Joseph. } \\
\text { S. D. Trotter. } \\
\text { Do. E. Dowd } \\
\text { Do }\end{array}$ & \multirow[t]{2}{*}{\begin{tabular}{|c} 
Columbia Steel Co \\
Metals Reserve Co do
\end{tabular}} & $\begin{array}{l}37 \\
14.7 \\
64 \\
145 \\
274\end{array}$ & $\begin{array}{l}27 \\
17 \\
12.4 \\
16 \\
16.5\end{array}$ \\
\hline & Total and average.. & & 535 & 16.8 \\
\hline
\end{tabular}

The ore occurs in a limestone bed, which corresponds with limestone B in the Staats and Pratt mines, at its intersection with a well-marked fault zone. All the ore is oxidized and, as the shipments indicate, is mostly low in grade. It is presumed, by analogy with the Black Boy area, to have been formed from primary manganese carbonate.

Development is insufficient to permit an accurate evaluation of the reserves. However, there are undoubtedly several thousand tons of material containing 10 to 15 percent manganese. The quantity of higher-grade ore appears to be very small.

\section{LAST CHANCE PROPERTY}

The Last Chance property, owned by D. Boyd and associates of Provo, consists of nine claims in the SE 34 sec. 6, T. 15 S., R. 10 W., $21 / 2$ miles southeast of the Staats and Pratt mines. It was examined by J. A. Straczek and Ralph J. Roberts, who report that 95 tons of ore averaging 25.6 percent manganese was shipped from a 90 -foot adit and several open pits. The ore exposed is manganese oxide that occurs along the bedding at the base of a dolomite zone corresponding 
with limestone B of the Staats and Pratt mines. This zone has been stoped for a length of 35 feet, a width of about 10 feet, and a thickness of 3 feet. The material in the face of the stope appears to be low in grade.

\section{BLACK DIAMOND MINE}

The Black Diamond mine, owned by J. J. Booth and associates, is in the center of sec. 6, T. 15 S., R. 10 W., about 2 miles southeast of the Staats and Pratt mines. The property was examined by J. A. Straczek and Ralph J. Roberts in 1941. It is reported that a small quantity of ore has been produced. The workings consist of a 20foot shaft and several pits, and the manganese oxides occur in small masses along bedding planes and fractures in limestone $\mathrm{B}$ of the Staats and Pratt mines near its intersection with a porphyry dike. The material is low in grade, and the tonnage appears to be small.

\section{MARTHA PROSPECT}

The Martha prospect is in the Drum Mountains, half a mile south of the Utah Central mine, on the north edge of sec. 1, T. 15 S., R. 11 W. It was examined by J. A. Straczek and Ralph J. Roberts in 1941. Apparently manganese oxides were encountered while the property was being explored in search of gold. They occur in small quantities in and adjoining masses of jasperoid or along faults in limestone. A small quantity of material containing 30 to 40 percent manganese was observed in two shafts and several open-cuts.

\section{BLACK HAWK CLAIM}

A claim known as the Black Hawk was located in 1918 by Pete Ericksson in sec. 25, T. 14 S., R. 11 W. J. T. Pardee states in unpublished notes that it was reported in 1918 to be a lode 10 feet or more wide between quartzite and limestone. It was probably in the vicinity of the present Staats and Pratt mines.

\section{VERDUN CLAIM}

This is an old claim in sec. 25, T. 14 S., R. 11 W., located in 1918 by Robert Wendt. Assays reported in unpublished notes by J. T. Pardee show 41 to 42.5 percent manganese.

\section{MANGANESE KING AND MANGANESE RING No. 1 CLAIMS}

Juab County records show that Herbert A. Parkyn, R. E. Clapp, C. M. Clapp, and G. T. Holliday located claims in the $\mathrm{SE}^{1 / 4}$ sec. 25, T. 14 S., R. 11 W., in 1918 . They were probably on what is now the Starts mine property.

\section{PIOTE COUNTY}

BLUE MIAMI MOON NO. 1 CLAIM

The Blue Miami Moon No. 1 claim is 14 miles east of Marysvale, about 500 feet north of the road to Manning Creek. It is owned by 
Mrs. Forrest King and E. F. Shauer of Marysvale and was visited by J. H. Wiese and G. L. Bell in September 1942.

A fault striking east and dipping $85^{\circ} \mathrm{N}$. cuts massive andesite. This structure has been developed by a 20 -foot adit and an 18 -foot shaft and is exposed for a length of 50 feet. Hard manganese oxide fills fractures for a width of 5 feet in the footwall and is highest in grade in a zone 2 feet wide adjacent to the fault. The hanging wall is barren. At the collar of the shaft, the grade of the ore is nearly 20 percent manganese over a width of 2 feet; at the bottom of the shaft the grade is about 10 percent manganese. It is reported that a carload of ore averaging 40 percent manganese was shipped during World War I. Fifteen tons of hand-sorted ore was stockpiled at the mine.

\section{BLACKBIRD CLAIMS}

The Blackbird group of six claims is at an altitude of 7,300 feet on the west slope of the mountains 5 miles east of Marysvale. The distance by road is 14 miles. The claims were owned by Max Krotke and Don Stocks of Marysvale, when examined by J. H. Wiese and G. L. Bell in 1942, and were leased to the Combined Metals Reduction Co. Development at that time consisted of a 24 -foot adit and two open pits.

The country rocks are andesite flows, flow breccia, and tuff, striking north and dipping $10^{\circ}-20^{\circ} \mathrm{E}$. The manganese occurs as veinlets of pyrolusite that are confined almost entirely to fractures in a flow breccia member 12 feet thick. The mineralization is strongest near a small fault at the north end of the deposit and becomes weaker to the south. There is apparently no mineralization north of the fault. An $8 y_{2}$-foot sample of the manganiferous zone from the northernmost open-cut adjoining the fault was assayed by the U. S. Bureau of Mines and found to contain 17 percent manganese. A similar sample from the adit 60 feet to the south assayed about 14 percent manganese. The face of the adit appears to be considerably lower in grade.

About 35 tons of hand-sorted ore thought to average about 20 percent manganese has been stockpiled in front of the north pit. In addition, the deposit probably contains several hundred tons of material averaging 10 to 20 percent manganese and several thousand tons containing 5 to 10 percent manganese.

\section{DRY CANYON CLAIMS}

The Dry Canyon group consists of 11 claims owned by $\mathbf{E}$. Nay and leased in 1942 to E. Gull. They were examined by M. E. Willard in - November 1942. Manganese oxides occur in nearly vertical northstriking fissures which have been developed by a 60 -foc $t$ adit and 15 
feet of trenches. The country rock is the Bullion Canyon volcanics. A vein averaging 2 feet in width is exposed along the strike for a distance of 250 feet. Throughout the rest of the claims there are small veins at many places, and the talus contains many fragments of vein material.

The grade of the ore apparently is 25 to 35 percent manganese. Exposures indicate that there may be a few thousand tons of such material, but the veins are so narrow that mining may not be practical.

\section{GILBERT CLAIMS}

The occurrence of manganese in the Ohio mining district in Durker Canyon has been reported by engineers of the U. S. Bureau of Mines. Stains and scattered oxide nodules are present in altered volcanic rocks on claims owned by Jonas Gilbert and a Mr. Taylor.

\section{RICH COUNTY}

\section{LAKEVIEW CLAIMS}

The Lakeview claims, owned by Wilson Newcomb, of Ogden, are in the NW $1 / 4$ sec. 9, T. $12 \mathrm{~N}$., R. $6 \mathrm{E}$., on the north slope of a low rounded ridge, near the summit of the Bear River Plateau, 3 miles southeast of Laketown. The deposit was examined by the writer in April 1946.

The geology of the area southeast of Laketown has been described briefly by Richardson (1941). The country rock is the gray Madison limestone; the bedding is obscure, and the attitude is uncertain. An inclined shaft follows a vein of calcite and pyrolusite that strikes $\mathrm{N}$. $70^{\circ} \mathrm{E}$. and dips $70^{\circ} \mathrm{S}$. At a depth of 20 feet, a drift extends 20 feet to the southwest, and in the face the vein is a few inches to 2 feet thick. The manganese mineral appears to be pyrolusite in a matrix of calcite. A 1-ton sample of the ore from the shaft taken by the Bureau of Mines for metallurgical tests contained 21.3 percent Mn, 24.9 percent $\mathrm{SiO}_{2}, 19.0$ percent $\mathrm{CaO}$, and 0.10 percent $\mathrm{P}$. The ore could probably be hand-sorted to yield a product containing 35 to 45 percent manganese, but the quantity of such ore appears to be relatively small.

Seventy-five feet north of the incline is the collar of a caved and partly filled vertical shaft. This was apparently sunk on an irregular zone of manganese- and iron-stained jasperoid that crops out around the collar. A 1-ton sample of the material exposed at the top of the caved shaft was taken by the Bureau of Mines for metallurgical tests. It contained 19.6 percent $\mathrm{Mn}, 31.2$ percent $\mathrm{SiO}_{2}, 16.6$ percent $\mathrm{CaO}$, and 0.09 percent $P$.

A short distance east of the caved shaft is a shallow pit in which is exposed considerable siliceous iron oxide. The material appears to 
be vuggy hematite in which the numerous cavities are lined with radiating crystals of goethite.

\section{SALT LAKE COUNTY}

\section{MANGANESE LODE PROPERTY}

The production records of the U. S. Bureau of Mines show that Sterling and Williams shipped 46 tons of ore from a property by this name in 1926. The ore averaged 25.2 percent $M n$ and 17.4 percent $\mathrm{SiO}_{2}$. The property has not been located, although it is thought to be in the Bingham district.

\section{EVANS LIME QUARRY}

The Evans lime quarry is in the NW1/4 sec. 27, T. 4 S., R. 1 W., about a mile northwest of Camp Williams. It was examined by the writer in April 1946. The quarries are on a small knoll about 50 feet below the highest shore line of ancient Lake Bonneville. The knoll is formed by calcareous tufa or travertine and is covered with a thin veneer of lake deposits and recent gravel. Marsell (1932) has described this occurrence and reports that vertebrate fossils found within the tufa are early Pleistocene in age. Four semicircular pits up to 200 feet across and as much as 30 feet deep were excavated during removal of the travertine for use in cement and plaster. Manganese oxides were discovered accidentally in the bottom of the pits during the mining. The recorded production is given in table 9 .

The ore occurs as irregular waddy masses that replace or fill the interstices between the blocks of travertine. Most of the ore is of the low-grade, waddy type, carrying a large percentage of clay or calcite. Locally, however, such material contains nodules of high-grade, steelgray, granular pyrolusite, half an inch to 5 inches in diameter. Thin veinlets of the same mineral were observed cutting the wad. Material of this sort, reported to have come "from the Jordan Narrows," was found by the Geological Survey laboratory to contain 92 percent $\mathrm{MnO}_{2}$.

TABLE 9.-Manganese-ore production, Evans lime quarry, Salt Lake County, Utah

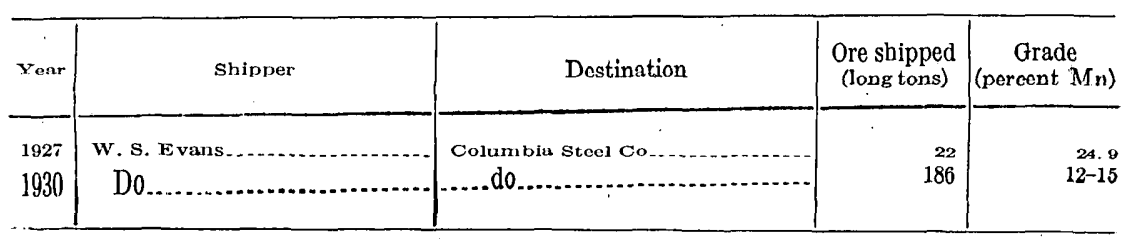

The travertine in which the manganese occurs is generally massive but banded by zones of varying porosity. It varies greatly in strike, and the dip ranges from horizontal to $40^{\circ}$. From surface exposures 
outside the pits it is inferred that the variations in dip are due to the initial dip of the travertine, which in one place appears to have a circular strike and to dip radially outward. At many places in the pits the travertine is broken into large blocks which may have slumped somewhat owing to solution. The travertine is presumed to have been deposited by water from springs.

The exact relation of the manganese to this process is not readily apparent. The occurrence of the manganese oxides in well-defined veins (Marsell, 1932, pp. 51-56) suggests that they were deposited later than the main mass of the travertine. There is no proof that the manganese came from the same springs that formed the travertine, but, in the absence of any other manganese deposits in the area, this seems the most likely source.

\section{MICHIGAN-UTAH PROPERTY}

The property of the Michigan-Utah Consolidated Mines Co. is in sec. 33, T. 2 S., R. 3 E., about a mile northeast of Alta, Utah, at the head of Grizzly Creek, on the divide between Little Cottonwood and Big Cottonwood Creeks. Manganese oxides were found along a vein in limestone north of the City Rocks fissure. Calkins and Butler (1943, p. 133) report that "where exposed, the manganese vein has a width of 10 to 15 feet, but its thickness evidently varies greatly from place to place." The following production is recorded:

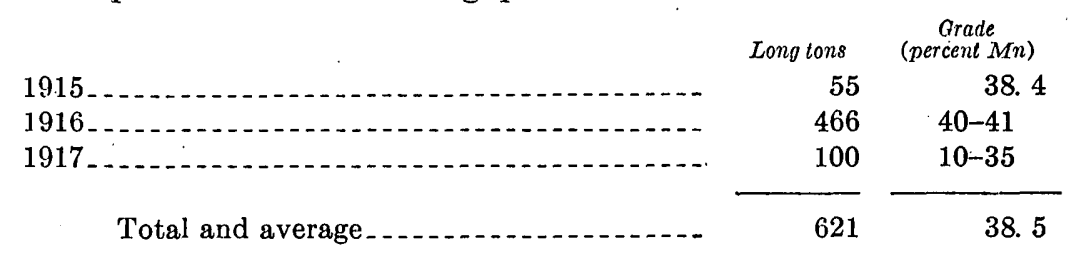

Although only manganese oxides were observed in the MichiganUtah mine, rhodochrosite was present in the deeper levels of the Cardiff mine nearby. There seems little reason to doubt that the manganese ore in the Michigan-Utah mine is of hypogene hydrothermal origin.

\section{SANPETE COUNTY}

\section{UNNAMED PROSPECT}

Manganese oxides assaying as much as 38 percent manganese are reported in unpublished notes by J. T. Pardee dated 1918 to occur mixed with jasper on a property owned by George A. Udall and others 8 miles northwest of Mount Pleasant. 


\section{SEVIER COUNTY}

\section{YELLOW HORNET PROPERTY}

The production records of the U. S. Bureau of Mines show that Messrs. Clayburn and Dalton operated from a property near Monroe or Annabella in 1941 and mined 7 tons of material averaging 23.6 percent manganese.

\section{NOONDAY PROSPECT}

The Noonday prospect, owned by Orson and John Naser and Clifford Sullivan, is in T. 25 S., R. 3 W., at a point 2 miles southeast of Monroe. It was examined in July 1940 by engineers of the U. S. Bureau of Mines, who report that pyrolusite occurs in brecciated andesite. A few hundred pounds of material averaging 25 percent manganese has been stockpiled by hand sorting.

\section{JUMBO PROSPECT}

A prospect known as the Jumbo, owned by Orson and John Naser and Victor and Clifford Sullivan, was examined by engineers of the U. S. Bureau of Mines in July 1940. It is reported to be located 6 miles south of Monroe. Manganese ore occurs in flat-lying limestone beds 1 to 15 feet thick; the reported grade is 10 to 12 percent manganese.

\section{GEORGIA MINE}

The Georgia mine, also known as the Loring property, is in T. 26 S., R. 3 W., at the base of Monroe Peak, 6 miles south of Monroe. It was owned by Mrs. M. J. Loring and was leased to Charles Wilkes in 1916 and A. Bjorman in 1918. It is now owned by Mrs. George Le Baron, of Kingman, Ariz. The production given in table 10 is reported in unpublished records, dated 1917, by V. C. Heikes.

Manganese oxides apparently occur in veinlets in weathered igneous rocks. Float is scattered over an area sevęral thousand feet in diameter.

TABLE 10.-Manganese-ore production, Georgia mine, Sevier County, Utah

\begin{tabular}{|c|c|c|c|}
\hline Year & Shipper & $\begin{array}{l}\text { Ore shipped } \\
\text { (long tons) }\end{array}$ & $\begin{array}{l}\text { Grade (per- } \\
\text { cent Mn) }\end{array}$ \\
\hline \multirow[t]{2}{*}{$\begin{array}{l}1916 \\
1918\end{array}$} & $\begin{array}{l}\text { Charles S. Wilkes } \\
\text { A. Bjorman }\end{array}$ & $\begin{array}{l}150 \\
250\end{array}$ & $\begin{array}{l}32 \\
50\end{array}$ \\
\hline & Total and average . . . . & 400 & 40 \\
\hline
\end{tabular}

\section{SUMMIT COUNTY \\ ONNAMED PROSPECT}

Fine-grained pyrolusite (or manganite) with some psilomelane is said to occur as cement in a conglomerate on a property 3 miles south- 
east of Coalville. The information was reported in a letter from the county surveyor in February 1916.

\section{PARK CITY DISTRICT}

\section{ONTARIO MINE}

Rhodonite and possibly rhodochrosite are reported (Boutwell, 1912, pp. 112-113) to occur in the Ontario mine in a vein carrying galena, pyrite, and sphalerite. This property is in the $\mathrm{NE}^{1 / 4}$ sec. 28 , T. $2 \mathrm{~S}$., R. 4 E.

\section{SILVER KING PROPERTY}

Manganese oxides assaying up to 49 percent manganese are reported by Pardee in unpublished notes dated 1918 to occur on various dumps of the Silver King Coalition Mines Co. in sec. 20, T. 2 S., R. 4 E. As far as is known, no ore has been shipped.

\section{TOOELE COUNTY}

\section{OPHTR DISTRICT}

\section{OPHIR HILL MINE}

Manganese ore is reported to have been shipped from the Ophir Hill mine in the $\mathrm{E} / 2$ sec. 23, T. 5 S., R. 4 W. The production is given in table 11.

This occurrence is described by Gilluly (1932, pp. 150-151) as follows:

Twelve carloads of manganese ore was mined during the World War by the Ophir Hill Consolidated Co. from the Bowman limestone, just south of the Canyon fault on the spur between Hartmann Gulch and the gulch in which the easterly outcrop of Tintic quartzite occurs. The ore was all oxidized, consisting of pyrolusite, psilomelane, and wad, undoubtedly secondary after manganiferous calcite. The ore was localized in the hanging wall and along branches of a fissure that trends due east and dips $80^{\circ} \mathrm{N}$. The limestone has been replaced through a vertical distance of about 60 feet and locally to distances of 6 to 8 feet to the side of the fissures. Certain limestone beds appear to have been selectively replaced, leaving nodular limestone residua convex toward the fissures, but on the whole the irregular minor fractures that abound in the rocks have guided the replacement. Mining was done by the room and pillar method.

A 2-ton sample of ore from the Ophir Hill mine was obtained by the Bureau of Mines for metallurgical tests. It consisted of pyrolusite and psilomelane in a gangue that contained appreciable quantities of claylike material. The assay results are as follows: $\mathrm{Mn}, 26.6$ percent; $\mathrm{SiO}_{2}$, 8.9 percent; $\mathrm{Fe}, 2.65$ percent; $\mathrm{Zn}, 0.50$ percent; $\mathrm{P}, 0.009$ percent. The Bureau concluded that the Ophir Hill ore was readily amenable to beneficiation by simple washing and gravity methods. 
TABLE 11.-Manganese-ore production, Ophir Hill mine, Ophir district, Tooele County, Utah

\begin{tabular}{r|r|r|r}
\hline Year & Shipper & $\begin{array}{l}\text { Ore shipped } \\
\text { (long tons) }\end{array}$ & $\begin{array}{r}\text { Grade (per- } \\
\text { cent Mn) }\end{array}$ \\
\cline { 2 - 4 } 1917 & $\begin{array}{c}\text { Ophir Hill Consolidated Mining Co } \\
\text { Do }\end{array}$ & & 46 \\
\hline
\end{tabular}

COLUMBIA DISTRICT

BENMORE MINE

The Benmore mine, also known as the Larson-Winberg mine, comprises among others the April Shower claim and the Black Crow Nos. $1,2,3$, and 4 . It is near the head of Harker Canyon, on the east side of the Sheeprock Mountains, about 9 miles south-southwest of Vernon. By road, the distance is approximately 12 miles. The mine is owned by Elmer E. Larson and Elmer Winberg and was examined by A. A. Baker and D. C. Duncan in September 1940.

The mine was operated by C. W. Jenkins in 1930 and 1931 and again in 1936 and 1937. The production given in table 12 is partly recorded and partly estimated; it also includes the production of the Sharp mine.

TABLE 12.-Manganese-ore production, Benmore and Sharp mines, Columbia district, Tooele County, Utah

\begin{tabular}{|c|c|c|c|}
\hline Year & Shipper & $\begin{array}{l}\text { Ore shipped } \\
\text { (long tons) }\end{array}$ & $\begin{array}{l}\text { Grade (per- } \\
\text { cent Mn) }\end{array}$ \\
\hline \multirow[t]{2}{*}{$\begin{array}{l}1930 \\
1936 \\
1937\end{array}$} & $\begin{array}{l}\text { C. W. Jenkins. } \\
\text { Do } \\
\text { Do }\end{array}$ & $\begin{array}{r}875 \\
527 \\
94\end{array}$ & $\begin{array}{r}20-25 \\
29.7 \\
31.6\end{array}$ \\
\hline & Total and average... & 1,496 & 25 \\
\hline
\end{tabular}

Manganese oxides crop out for a distance of 300 feet on the north side and near the crest of a narrow ridge. The ore occurs in shattered quartzite as impregnations and spongy masses that form irregular elongate bodies. Most of the material probably contains 10 to 20 percent manganese, but irregularly shaped pockets of richer ore as much as 10 feet in diameter are present.

Nearly barren quartzite occurs both above and below the ore and between the lenticular masses. The manganiferous zone dips a few degrees southwest, although the quartzite dips almost vertically.

\section{SHARP MINE}

The Sharp mine consists of five patented claims, owned by Emma S. Sharp of Vernon, Utah. It is located near the head of a canyon half a mile south of Harkers Canyon, approximately 9 miles south- 
southwest of Vernon. The property was examined by A. A. Baker and D. C. Duncan in September 1940. It was first operated by J. A. Sharp in 1925. Later, in 1930-31 and again in 1936-37, it was operated by C. W. Jenkins in conjunction with the nearby Benmore mine. The actual tonnage produced by each mine has not been determined, and the production from the last operation is included with that of the Benmore mine in table 12.

A manganiferous zone in Tintic(?) quartzite is exposed in pits and adits for a distance of 100 feet. The ore is in veinlets or in nearly structureless masses of spongy oxide, associated with clayey material suggestive of fault gouge. Crude stratification in the deposit suggests that the main plane of the deposit dips about $20^{\circ} \mathrm{S}$. The average grade of the ore in place is probably 20 to 25 percent manganese. It can be selectively mined, however, at a somewhat higher grade, as indicated by a 2 -ton sample of ore, taken from the ore bin by the U.S. Bureau of Mines for metallurgical tests, which assayed 29.8 percent $\mathrm{Mn}, 19.1$ percent $\mathrm{SiO}_{2}, 7.6$ percent $\mathrm{Fe}, 7.7$ percent $\mathrm{Al}_{2} \mathrm{O}_{3}$, and 0.45 percent $\mathrm{Zn}$.

\section{TOOELE AND JUAB COUNTIES}

\section{ERICKSON DISTRICT}

The Erickson mining district is in the southern part of the Simpson Mountains, 40 miles north of Delta. It is on the boundary between Tooele and Juab Counties, in unsectioned T. 10 and 11 S., R. 7 and $8 \mathrm{~W}$. The sections shown on the inset map (pl. 1) are projected, and mine locations are necessarily approximate.

The geology of the region has been briefly described by Loughlin (Lindgren and Loughlin, 1919, pp. 447-448), and the manganese deposits have been described by Pardee (1921, pp. 208-209). The rocks in most of the area are Cambrian quartzite, shale, and conglomerate, with a few dikes of a later intrusive prophyry. The general strike is northwest, and the dip is about $45^{\circ} \mathrm{NE}$. These rocks are cut by numerous steep faults, along which manganiferous quartz veins carrying lead, zinc, and silver have formed. Most of the development in the area has been in search of silver, but showings of manganese have been reported from at least seven properties.

The veins are mostly narrow but locally widen to as much as 15 feet. From the surface to a depth of 100 feet or more the ore is a cavernous mixture of quartz, altered country rock, and manganese and iron oxides. Below the limit of oxidation the ore is dense, and the primary manganese minerals rhodonite and rhodochrosite are present. The fresh rock is a pale cream-colored or pinkish aggregate, containing considerable pyrite and, usually, small amounts of galena, sphalerite, and chalcopyrite. 
Thus all the deposits of the district belong to the group of hypogene, hydrothermal deposits in which the manganese is associated with precious and base metals.

\section{BLACK ROCK CLAIMS}

The Black Rock is a group of seven claims also known as the Baby Elephant, Strang, Evening Star, or Huber-Rydalch deposit. It is at an altitude of about 6,000 feet in Death Canyon, on the south slope of the Simpson Mountains, in sec. 23, T. 10 S., R. 8 W. Roads leading to this and other properties in the area branch from the Jericho-Callao road about 28 miles west of Jericho. The property is owned by A. T. Huber and Ross Rydalch and was leased to Orville Olson in 1936 and C. A. Elkins in 1944.

The mine was developed in search of silver before World War I, but there is no record of production. Although the deposit was known in 1918 to contain manganese, none was shipped until 1935. Table 13 gives the known production of manganese.

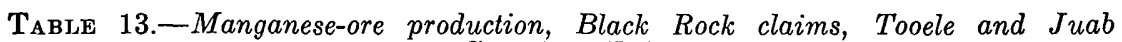
Counties, Utah

\begin{tabular}{|c|c|c|c|c|}
\hline Year & Shipper & Destination & $\begin{array}{l}\text { Ore shipped } \\
\text { (long tons) }\end{array}$ & $\begin{array}{c}\text { Grade } \\
\text { (percent Mn) }\end{array}$ \\
\hline \multirow[t]{2}{*}{$\begin{array}{l}1936 \\
1944\end{array}$} & $\begin{array}{l}\text { Orville Olson........ } \\
\text { C. A. Elkins } . . . . . .\end{array}$ & \multirow[t]{2}{*}{$\begin{array}{l}\text { Columbia Steel Co } \\
\text { Geneva Steel Co }\end{array}$} & $\begin{array}{r}150 \\
482 \\
\end{array}$ & $\begin{array}{r}20-30 \\
25\end{array}$ \\
\hline & Total and av & & ${ }^{1} 630$ & 25 \\
\hline
\end{tabular}

Approximate figure.

In the summer of 1942 the deposit was trenched and sampled by the Bureau of Mines as part of the strategic-minerals investigation for that year. A description of this work has been published (Fry and Wilson, 1949). A. E. Granger and A. F. Shride, of the Geological Survey, mapped the surface and the accessible workings, and the following account was written almost entirely by them.

The manganese deposits on the Black Rock claims are partly oxidized hydrothermal vein deposits formed along major faults that cut quartzite, conglomerate, and phyllite of Cambrian age. These rocks are all part of the Tintic quartzite; they strike approximately north and dip $20^{\circ}-25^{\circ} \mathrm{E}$. North of the major fault zone the exposed rocks are brown, coarse-grained quartzite and conglomeratic quartzite containing pebbles of fine-grained white quartzite in a brown matrix; south of the fault only finer-grained white quartzite is exposed. Brown phyllite crops out in a small fault sliver in the southeast corner of the area.

Two faults are exposed in the mine area. The larger strikes northwest, dips vertically, and is marked by a brecciated zone 20 to 100 feet 
wide. This fault is joined by the second, smaller fault, which strikes nearly east, dips steeply, and forms a breccia zone that rarely exceeds 5 feet in width. Both the faults are more or less mineralized.

The manganese oxide ore bodies are of two types, one type formed by the oxidation in place of manganiferous veins, the other formed by the migration of manganese oxides from the primary veins into the adjoining brecciated wall rocks.

Two bodies of manganese oxide ore averaging 20 to 25 percent manganese lie along the east-striking fault already described. They consist of pyrolusite and wad in a gangue of quartz, calcite, gouge, and brecciated quartzite. The east adit encountered this material to a depth of about 100 feet below the surface, where the oxides change rather abruptly to a dense vein which contains some rhodonite, rhodochrosite, pyrite, galena, and sphalerite in a gangue of quartz and calcite. In general, the oxide ore bodies of this type average 20 to 25 percent manganese; there is much material of lower grade on the margins.

Several bodies of the "transported" type of manganese oxide are found along the larger fault zone on the west side of the canyon. In this type, manganese oxides occur as thin coatings, fracture fillings, and stains in irregular pipelike bodies that appear to be formed along local faults and openings. There is no evidence that they are derived from primary manganiferous veins.

There is a substantial reserve of low-grade manganese oxide ore at this group of claims. Part of this ore will average 20 to 25 percent manganese, but a much larger additional tonnage will average 10 to 20 percent manganese. If only those parts of the veins are considered that are 4 feet or more thick and that contain more than 10 percent manganese, there are six distinct ore bodies, separated by zones of barren or lower-grade material. None of the material below the water table can be included, inasmuch as the manganese present as rhodonite is not normally recoverable. The exact grade of material that can be mined profitably will depend upon market conditions and other economic factors, and possibly much of the low-grade material contained in some of the ore bodies may never be economically recoverable.

\section{BLACK JACK (MORGAN-CROMAR) CLAIMS}

The Black Jack, or Morgan-Cromar, group of claims is in the NE1/4 sec. 25 (projected), T. 10 S., R. 8 W., on the east side of Blaine Canyon in the south end of the Simpson Mountains. It is owned by James Morgan, of Eureka, and was leased in 1918 to Wright and Williams and to Price and McCarthy and in 1943 and 1944 to N. W. Brown. Table 14 gives the recorded production. 
TABLE 14.-Manganese-ore production, Black Jack (Morgan-Cromar) claims, Tooele and Juab Counties, Utah

\begin{tabular}{|c|c|c|c|c|}
\hline Year & Shipper & Destination & $\begin{array}{l}\text { Ore shipped } \\
\text { (long tons) }\end{array}$ & $\begin{array}{l}\text { Grade (per. } \\
\text { cent Mn) }\end{array}$ \\
\hline \multirow[t]{2}{*}{$\begin{array}{l}1918 \\
1944\end{array}$} & $\begin{array}{l}\text { Thomas L. McCarthy } \\
\text { Norven W. Brown }\end{array}$ & $\begin{array}{l}\text { Not known } \\
\text { Metals Reserve Co }\end{array}$ & $\begin{array}{r}125 \\
19\end{array}$ & $\begin{array}{l}40.3 \\
44.8\end{array}$ \\
\hline & Total and average..... & - & 145 & 41 \\
\hline
\end{tabular}

The property was examined in 1918 by J. T. Pardee (1921, pp. 209-210), who describes the mine as follows:

The country rock is gray to brown weathering quartzite, with intercalated layers of gray to green micaceous shale or slate. A short distance to the east is a large dike of intrusive porphyry. The quartzite and shale strike northwest and dip about $45^{\circ} \mathrm{NE}$.

On the Black Jack No. 4 a northward-trending lode about 6 feet wide composed of sheared country rock, vein quartz, and manganese oxides is exposed by shallow pits for 75 feet or more. At the south is a shaft 60 feet deep, with a drift at the bottom extending 40 feet north. This working shows 2 feet of ore on a smooth wall from the surface to a depth of about 20 feet. Below this the wall is not exposed, the shaft and the drift being entirely in rather low-grade manganiferous material. A stope above the drift 20 feet long, 15 feet wide, and 15 feet high does not show the limits of the body.

The deposit is somewhat loose, friable, and cavernous and consists of manganese oxides and clayey matter, mainly kaolin and quartz sand, that form bunches and streaks. The manganese oxides are chiefly psilomelane, with some pyrolusite and a little wad. The psilomelane forms nodules, concretions, and irregular streaks in which thin layers of pyrolusite are commonly inclosed. Free crystals of pyrolusite and films of sooty wad line some of the cavities. In mining about half the mass is selected for shipment. Samples of two cars yielded, respectively, 41.9 and 44.85 percent of manganese, 8.34 and 9.6 per cent of silica, 3.3 and 3.0 per cent of iron, and 0.044 and 0.45 percent of phosphorus.

On the Black Jack No. 2 a manganiferous body 30 feet long and 20 feet wide crops out. It consists of a light, somewhat leathery porous material, chiefly wad and decomposed country rock. Bunches of good-looking ore, chiefly pyrolusite, appear in places. The deposit is cut by an adit level at a depth of 70 feet and explored 40 feet deeper by a winze. In these workings it ranges from 6 inches to 6 feet in width and lies on a bedding plane in quartzite that strikes north and dips $45^{\circ} \mathrm{E}$ : Bunches of good ore are found in places, but most of the material is like that in the outcrop, which is said to average about 30 per cent of manganese. A small shipment of ore is reported.

On the Black Jack claim, about a quarter of a mile north of the Black Jack No. 4, a deposit of manganese oxides is exposed by an inclined shaft 100 feet deep. This body lies on a bedding plane in quartzite that strikes $\mathrm{N}$. $35^{\circ} \mathrm{W}$. and dips $45^{\circ} \mathrm{NE}$. It is of tabular form, 2 feet thick at the surface, and rather uniformly 4 feet thick from a depth of 60 feet to the bottom. On one side of the shaft the deposit consists of light, porous leathery manganese oxide like that in the Black Jack No. 2. On the other side it is largely pyrolusite and apparently will yield ore of good grade. About 500 feet northwest of this working a 50-foot shaft exposes a few bunches of ore, presumably in the same lode. All the workings described are dry, and no unoxidized ore was seen. 
Since 1918, at least one of the workings has been extended to the water table, and the primary manganese ore is reported to resemble closely that at the Black Rock group. Mr. Morgan reports that a high-grade vein of galena was found in the lower part of the workings. Four samples of manganese ore from the Black Jack group were taken by the Bureau of Mines for metallurgical tests (table 15).

TABIE 15.-Assay by U. S. Bureau of Mines of metallurgical samples from Black Jack (Morgan-Cromar) claims, Tooele and Juab Counties, Utah

\begin{tabular}{r|r|r|r|r|r|r}
\hline \multicolumn{1}{c|}{ Sample } & $\mathrm{Mn}$ & \multicolumn{1}{c|}{$\mathrm{SiO}^{2}$} & $\mathrm{Fe}$ & $\mathrm{S}$ & $\mathrm{Ph}$ & $\mathrm{Zn}$ \\
\hline $\mathrm{A}$ & 25.7 & 19.6 & 6.7 & 0.3 & 0.5 & 1.2 \\
$\mathrm{~B}$ & 39.3 & 8.0 & 4.3 & .2 & .8 & .95 \\
$\mathrm{C}$ & 26.5 & 27.8 & 4.1 & .3 & .85 & .85 \\
\hline
\end{tabular}

A. Sample from Black Jack No. 2, inclined shaft.

B. Sample from Black Jack No. 1, collar of inclined shaft.

C. Sample from Black Jack No. 1, adit level.

D. Sample from Black Jack No. 3, inclined shaft.

\section{DEER TRAIL CLAIMS}

The two claims of the Deer Trail, or Black Cap, group are on Judd Creek, in the southeast edge of the Simpson Mountains near the north edge of sec. 29 , T. 10 S., R. 7 W. They are owned by J. T. O'Connor of Tooele, Utah, and were leased in 1925 to Morgan, McPhail, and Huffaker, in 1928 to Orville Olson, in 1942 to N. W. Brown, and in 1944 to C. A. Elkins. The information was given to the writer by O'Connor in 1946.

The manganese oxides occur in a manner closely resembling that of the Black Rock group. The ore of the fissures may at places assay 25 percent manganese, 22 percent lead, and a few dollars per ton in gold. Some copper minerals have been observed in the vicinity. The estimated production is given in table 16 .

TABLE 16.-Manganese-ore production, Deer Trail claims, Erickson district, Tooele and Juab Counties, Utah

\begin{tabular}{|c|c|c|c|}
\hline Year & Shipper & $\begin{array}{l}\text { Ore shipped } \\
\text { (long tons) }\end{array}$ & $\underset{\text { (percent Mn) }}{\text { Grade }}$ \\
\hline \multirow[t]{2}{*}{$\begin{array}{l}1931 \\
1936 \\
1943\end{array}$} & $\begin{array}{l}\text { C. W. Jenkins } \\
\text { Do W. Brown } \\
\text { N. Whe }\end{array}$ & $\begin{array}{r}625 \\
125 \\
12\end{array}$ & $\begin{array}{l}(?) \\
(?)\end{array}$ \\
\hline & Total and average.. & 1760 & $25-30$ \\
\hline
\end{tabular}

1 Approximate figure.

\section{INDIAN BOY CLAIM}

A deposit known as the Indian Boy claim is near the corner of secs. 28, 29, 32, and 33, 'T. 10 S., R. 8 W., near Six Mile Spring, on the west slope of the Simpson Mountains, about 2 miles from the Black Rock 
group. The mine was owned in 1918 by William Means and E. C. Bechtol but was later relocated by its present owner, L. E. Kramer. It was leased to Adam Cook and to Sammon and Toole in 1918 and to C. W. Jenkins in 1931. The production is given in table 17.

In 1918 the ore was reported by the owners to be manganese oxide resembling that of the Black Rock group. The country rock is quartzite and shale, striking east and dipping $35^{\circ} \mathrm{N}$. The manganese oxides apparently occur in replacement bodies as much as 15 feet thick.

TABLE 17.-Manganese-ore production, Indian Boy claim, Erickson district, Tooele and Juab Counties, Utah

\begin{tabular}{|c|c|c|c|}
\hline Year & Shipper & $\begin{array}{c}\text { Ore shipped } \\
\text { (long tons) }\end{array}$ & $\begin{array}{c}\text { Grade } \\
\text { (percent } \mathrm{Mn} \text { ) }\end{array}$ \\
\hline $\begin{array}{l}1930 \\
1931 \\
1939 \\
1940\end{array}$ & $\begin{array}{l}\text { L. E. Kramer (through C. W. Jenkins) } \\
\text { L. W. Jenkins } \\
\text { E. Kramer } \\
\text { Do Do. }\end{array}$ & $\begin{array}{r}60 \\
275 \\
22 \\
32 \\
34\end{array}$ & $\begin{array}{r}30-35 \\
30-35 \\
35.4 \\
32.4 \\
29.6\end{array}$ \\
\hline & Total and average & 423 & $30-35$ \\
\hline
\end{tabular}

UTONIA CLAIM

The Utonia claim is approximately in the $\mathrm{W} \frac{1}{2}$ sec. $26, \mathrm{~T} .10 \mathrm{~S}$, R. 8 W., on the side of Death Canyon south of the Black Rock group. Pardee (1921, p. 211) reports as follows:

Adits are made at altitudes of 6,400 and 6,800 feet on the Utonia claim. They explore a lode valuable for silver in which moderate amounts of manganese are found. Below the oxidized zone, which is 100 feet or more deep, the manganese occurs as rhodonite and rhodochrosite, with which pyrite, galena, and zinc blende are associated.

\section{MAY FARMER CLAIMS}

William B. Means reported to J. T. Pardee in 1918 that he owned the May Farmer group of six claims in the Simpson Mountains. Its exact location is not known. It was reported to be on a "blowout" of manganese oxides and jasper.

\section{QUEEN MARY CLAIMS}

The Queen Mary group of claims is reported by its owner, Nephi Anderson, according to unpublished notes by J. T. Pardee dated 1918, to cover a "blow-out" of manganiferous material resembling that in the Black Rock group. It was developed by small pits. The grade was estimated to be 25 percent manganese and 25 percent silica.

\section{UTAH COUNTY}

\section{WIIDCAT MINE}

The Wildcat mine, owned by Chester and Cloy Steele, of Santaquin, Utah, is at an altitude of 5,450 feet, on the west slope of the Lake Mountains about 7 miles southeast of Fairfield. It is in the $N W y_{4}$ 
sec. 9 , T: 7 S., R. 2 W. The property was examined by the writer in April 1946. Records of shipments are uncertain; table 18 embodies the best estimate that could be made.

TABLE 18.-Manganese-ore production, Wildcat mine, Utah County, Utah

\begin{tabular}{|c|c|c|c|c|}
\hline Year & Shipper & Consignee & $\begin{array}{l}\text { Ore shipped } \\
\text { (long tons) }\end{array}$ & $\begin{array}{c}\text { Grade } \\
\text { (percent Mn) }\end{array}$ \\
\hline 1930 & Steele Brothers. & Colorado Fuel and Iron Co.; Co- & 206 & $40-50$ \\
\hline $\begin{array}{l}1931 \\
1943\end{array}$ & $\begin{array}{l}\text { Dotal and average } \\
\text { To }\end{array}$ & $\begin{array}{l}\text { Columbia Steel Co Co } \\
\text { Metals Reserve Co.................. }\end{array}$ & $\begin{array}{r}100 \\
24 \\
230\end{array}$ & $\begin{array}{r}40-50 \\
43.5 \\
45\end{array}$ \\
\hline
\end{tabular}

The main shaft, at which the road ends, is an irregular $45^{\circ}$ incline about 200 feet deep, bearing $\mathrm{N} .70^{\circ} \mathrm{E}$. At a depth of about 75 feet the shaft is deflected toward the south and continues about 60 feet as a drift. Twenty feet from the end of the drift are a 30 -feet winze and a 10 -foot raise following the bedding. At a depth of 35 feet the shaft opens to the south into a narrow stope in which the ore was followed to the surface. Nowhere was the stope more than 15 feet from the shaft. Seventy-five feet south of the incline is an open pit 10 feet deep from which a small amount of ore was recovered, Across. the first small canyon to the north is a 75-foot adit, where the original discovery was made. A few small pits, 200 to 500 feet southeast of the incline, are the only other workings.

The main shaft, the small open pit, and the discovery adit are all within a single stratigraphic horizon that consists of thin-bedded fossiliferous shaly limestone with varying amounts of hard crystalline limestone in beds a few inches to a foot thick. Where they are unmineralized the beds are gray in color, but near the workings they are buff or brown and are softened and shaly in appearance. Bedding: faults are abundant throughout the workings connected with the incline and probably are the principal factors responsible for the localization of the ore in these beds. Below the ore horizon is a 4 -foot bed of coarsely crystalline fossiliferous limestone that torms the footwall of the ore. It is exposed at several places in the workings and has undergone considerable solution by ground water, as shown by its irregular surface and the presence of several water oourses. In the open-cut near the collar of the shaft, sheared shaly limestone occurs for a distance of approximately 15 feet below the footwall limestone. A few veinlets of manganese oxide were noted in these beds, but they have not been explored underground. The fossils indicate that these rocks are late Paleozoic in age, but more detailed information is lacking.

The ore occurs as intertwining veinlets and stringers following: bedding, bedding faults, or fractures. Locally, the veinlets widen and 
join to form irregular pockets and masses of ore up to a few feet in diameter. In several of the small pits, particularly those up the ridge east-southeast of the incline, the ore occurs along small faults that strike nearly east and dip almost vertically. In the only place where it could be observed, the fault had a normal displacement of a foot or two. Although the presence of such faults in the main workings could not be proved, there is a suggestion that the pipelike body mined in the stope south of the shaft may have been formed at the intersection of the thin-bedded limestone with a fault of this type. The inclined shaft was sunk in waste to a depth of 35 feet, but below this level the workings were mostly in ore, although considerable waste around and between the ore had to be handled.

The ore is hard blue-black cryptomelane that appears as slaggy, cavernous masses on which stalactitic or botryoidal forms are commonly developed. Almost all the masses are spongy and contain large cavities as well as numerous small openings. The larger masses are entirely free of visible gangue except near the edges, where the manganese mineral cements the wallrocks, but a considerable quantity of fine shale became mixed with the product in mining. Consequently, the grade of the ore shipped in 1943 was only 43.5 percent manganese. The grade of the clean ore should be considerably higher.

There is about 25 tons of altered, sheared limestone on the dump that contains 15 percent manganese in the form of fragments of hard oxide. If water was available nearby, such material could readily be milled and should yield 400-500 pounds per ton of concentrates averaging 45 to 50 percent manganese. There is only a little ore remaining in place underground, but additional ore might possibly be discovered along the beds to the north or south or in the footwall of the present workings. It appears unlikely, however, that such prospecting would be profitable except in periods of unusually high prices.

\section{TROTTER MINE}

The Trotter, or Long Ridge, mine is in the $\mathrm{W} 1 \frac{1}{2}$ sec. 9, T. $11 \mathrm{~S}$, R. $1 \mathrm{~W}$., on the point and west slope of a ridge that extends nearly north on the northwest slope of the mountains 6 miles south of Elberta. It is owned by S. D. Trotter, of Provo, Utah. The workings consist of an area nearly 400 feet long and 250 feet wide that has been stripped with a bulldozer. Several large open pits have been dug with a steamshovel in the mineralized area formerly worked by means of adits. The mine was examined by the writer in April 1946.

The production is given in table 19.

Most of the country rock is Cambrian limestone that strikes north to northwest and dips up to $45^{\circ} \mathrm{NE}$. It is best exposed on the ridge south of the highest workings. Farther south the slope of the ridge 
breaks abruptly at a fault, marked by a large mass of quartzite breccia. The block south of the fault has been shifted east, or upward, bringing Ophir shale in contact with the limestone.

TABLE 19.-Manganese-ore production, Trotter mine, Utah County, Utah

\begin{tabular}{|c|c|c|c|c|}
\hline Year & Shipper . & Destination & $\begin{array}{l}\text { Ore shipped } \\
\text { (long tons) }\end{array}$ & $\underset{\text { Grade }}{\text { (percent } \mathrm{Mn} \text { ) }}$ \\
\hline \multirow[t]{2}{*}{$\begin{array}{l}1924 \\
1935\end{array}$} & \multirow{2}{*}{$\begin{array}{l}\text { Duncan McVichie....... } \\
\text { Do } \\
\text { Do Do } \\
\text { Trotter Brothers. } \\
\text { Total and average.......... }\end{array}$} & \multirow{2}{*}{ 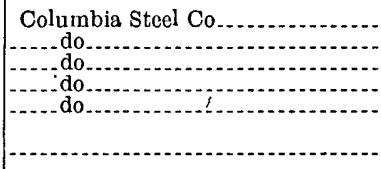 } & $\begin{array}{r}79 \\
50 \\
.102 \\
496 \\
163\end{array}$ & $\begin{array}{r}14.3 \\
37.95 \\
13.67 \\
8.8 \\
11.96\end{array}$ \\
\hline & & & 890 & 12.1 \\
\hline
\end{tabular}

Throughout the workings the limestone is sheared and altered, sometimes entirely "sanded." Most of the manganese appears to be associated with pebble dikes, jasperoid, or both, and most of the gangue is quite siliceous. One such zone occurs along a well-defined fault. striking N. $10-20^{\circ} \mathrm{E}$. and dipping $75^{\circ} \mathrm{E}$., but such faults were not recognized in more than one pit. Locally, certain beds appear to have been brecciated and selectively mineralized.

Only a small quantity of ore is visible in place. The best was found on the crest of the ridge where it was exposed by recent bulldozer stripping. It is dense, clinkery pyrolusite containing small. amounts of unreplaced altered limestone. This relatively high grade material was undoubtedly formed by local reconcentration. Most of the material in sight is high in iron and would average 10 percent manganese or less.

There appears to be little prospect of obtaining significant amounts of ore from this property.

\section{SPALDING CLAIMS}

The Spalding group comprises more than 20 claims, owned by T. F. Spaulding and J. C. Meiling. They are in a narrow wash about 2 miles northeast of Slate Jack Canyon, on the north slope of Long Ridge in secs. 9 and 16, T. 11 S., R. 1 W. They were examined briefly by the writer in April 1946 and by engineers of the U. S. Bureau of Mines. Manganese oxides occur along several small faults and bedding zones approximately at the top of the Tintic quartzite.

On the Aeronaut No. 1 claim, a low-grade zone reported to be 12 to 16 inches thick crops out for 40 feet in the bottom of the wash. A sample of this zone which was taken by the U. S. Bureau of Mines for metallurgical tests assayed 15.4 percent $\mathrm{Mn}, 16.0$ percent $\mathrm{SiO}_{2}$, 24.1 percent $\mathrm{Fe}, 10.3$ percent $\mathrm{Al}_{2} \mathrm{O}_{3}$, and 0.69 percent $\mathrm{P}$. 


\section{QUEEN OF THE WEST CLAIM}

Manganiferous iron ore, averaging 5 to 10 percent manganese, 40 to 50 percent iron, and 5 to 10 percent silica, is exposed on this claim and another adjoining it near the east edge of sec. 9, T. 11 S., R. $1 \mathrm{~W}$. They are in the Long Ridge Mountains, east of the Trotter mine and the Spalding group. Ownership is divided; the International Smelting and Refining Co. holds a half-interest. The property was leased to S. D. Trotter in 1917-18. This information was reported to the author in April 1946.

\section{SILVER HILL PROPERTY}

The production records of the U. S. Bureau of Mines show that D. Ewell shipped 33 long tons of ore averaging 17 percent $\mathrm{Mn}$ from Utah County in 1927. The source of this shipment was given as Silver Hill, but the location of the property is not known.

\section{UTAH AND JUAB COUNTIES}

\section{TINTIC DISTRICT}

The Tintic district is in the East Tintic Mountains 60 miles south of Salt Lake City, Utah. The Utah-Juab County line follows the crest of the range, and consequently the mines of the district are divided between the two counties. The rocks are Paleozoic quartzite and limestone that have been folded, intricately faulted, and intruded by Tertiary granitoid rocks. Tertiary lavas cover much of the area. The district is known principally for its precious- and base-metal deposits, which are among the richest in the country.

The geology and ore deposits have been described by Lindgren and Loughlin (1919). Many of the lodes contain traces of manganese, and some of them contain considerable quantities of lowgrade manganese oxides. Manganese ore has been shipped from at least eight properties, and the total production from the district exceeds 8,000 long tons of ore that averaged 24 to 25 percent muliganese.

The manganese, like the precious and base metals with which it is associated, is undoubtedly of hydrothermal origin. It is presumed that the oxides, which have constituted all the production, were derived from primary manganese minerals, the commonest of which are rhodochrosite and manganiferous calcite or ankerite (Pardee, 1921, p. 207). Nevertheless, rhodochrosite apparently was not observed by either Lindgren and Loughlin or Pardee, nor has it been found during recent studies, although skeletal outlines suggestive of rhombohedral shape were found, according to a personal communication from T. S. Lovering, in one specimen from the Oxen manganese mine. 


\section{TIP TOP TUNNEL}

The so-called "Tip Top tunnel," in the center of the $\mathrm{N} 1 \frac{2}{2} \mathrm{~N} 1 / 2$ sec. 9, T. 10 S., R. 2 W., is a 250 -foot adit driven into the south wall of Homansville Canyon 150 to 200 feet above Utah State Highway 6 and 90 feet below the crest of the ridge. The property was visited by the writer in April 1946. It is owned by the Chief Consolidated Mining Co. and, as indicated by the record of shipments, has been leased to a number of operators since 1916. According to Pardee (1921, p. 207), "it was run prior to 1917 to develop a silver lode and incidentally disclosed a deposit of manganese." The raise from the adit now opens into an open pit on the crest of the ridge. This pit is at least 60 by 30 feet in size and has been worked to a depth of 30 feet before narrowing to form a stope which connects with the underground workings. Several smaller pits have been dug along the ridge west and southwest of the large pit.

The recorded production is given in table 20 .

TABLE 20.-Manganese-ore production, Tip Top tunnel, Tintic district, Utah and Juab Counties, Utah

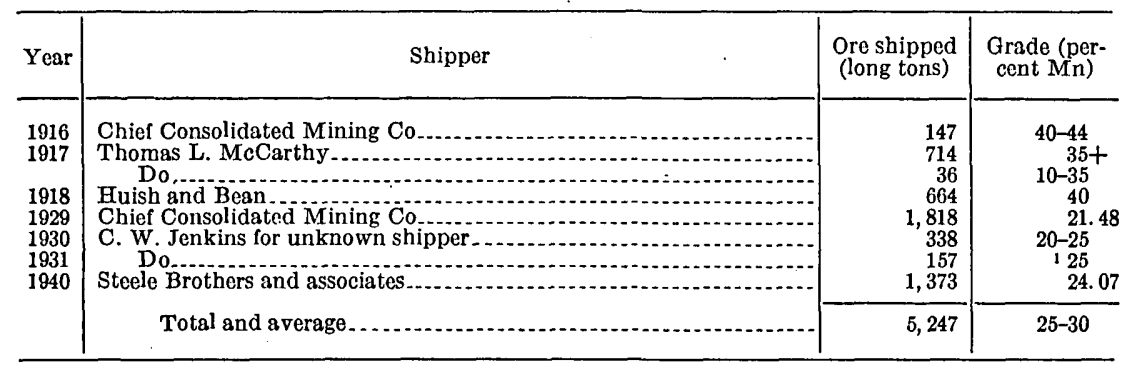

1 Assumed.

The occurrence and ore are described by Pardee (1921, p. 208) as follows:

The country rock is the Ordovician Opohonga limestone, described by Loughlin, which occupies a small area along the south side of Homansville Canyon. On weathered surfaces it shows a striped or mottled appearance caused by alternating thin layers of clayey material and relatively pure carbonate. Fresh exposures are uniformly light gray. Small streaks and bunches of manganese oxides crop out here and there along the ridge above the adit, in a belt 10 to 40 feet wide and 500 feet or more long. As shown by the workings, some of these streaks are offshoots from the body that is being mined.

The deposit explored by the adit is an irregular pod or pipelike body at least 90 feet long and from 3 to 40 feet in diameter. It pitches about $45^{\circ} \mathrm{S}$., and so far as the adit shows does not extend below the roof of the adit. It reaches the surface as one or more small veins that crop out near the middle of the manganiferous belt mentioned. The ore is cavernous, rather loose and friable in places, and made up chiefly of nodules and streaks of manganese oxides, with soft clayey material partly filling the spaces between. The oxides are intimately mixed, 
and so far as can be determined psilomelane is the most abundant. Commonly the smaller cavities are filled with wad or lined with free crystals of pyrolusite. The clayey material consists chiefly of kaolin and quartz, with small amounts of iron oxides.

The quantity and grade of ore remaining have not been carefully studied. Nevertheless, it appears probable that there is considerable ore left in smaller extensions of the body already mined, especially to the west. This material may be somewhat more expensive to mine, however, and owing to dilution may be somewhat lower in grade.

Concerning the origin of the deposit, Pardee (1921, p. 208) concludes:

The general features of the deposit, particularly its form and structure, indicate that it was formed by replacement of the limestone along fractures and bedding planes. The parent manganese mineral was probably rhodochrosite or a mixed carbonate, the oxidation of which would be accompanied by a shrinkage in volume sufficient to produce the cavernous texture of the ore. Presumably the manganese, like the silver and other metals of the district, was brought to place by ascending solutions whose source was some deep-seated rock.

\section{OXEN MINE}

The Oxen mine is on the ridge south of Homansville Canyon, about a quarter of a mile east of the Tip Top tunnel in the $\mathrm{NW}^{1 / 4}$ sec. 9 , T. 10 S., R. 2 W. It can be reached by a road that leaves Highway 6 just east of the Chief Consolidated pump house. It was. operated in 1944 by the Steele Brothers, who shipped 25.55 long tons. averaging 36.5 percent manganese to the Metals Reserve Co. and 749 long tons averaging 22.7 percent manganese to the Geneva Steel Co. The property was visited by the writer in April 1946.

The workings consist of a crescent-shaped open-cut, 175 feet long by 50 feet wide, in which there are small underhand stopes. The deepest of these stopes extends about 35 feet below the surface of the ground. The country rock is the Ordovician Opohonga limestone, which strikes northeast and dips $25^{\circ} \mathrm{NW}$. The ore is formed by replacement of the Opohonga limestone along bedding planes, joints, and fractures and along several faults. The largest of these faults is exposed in the northwest end of the pit, where it has been followed by a shallow inclined shaft started in the bottom of the pit. In this incline, the fault strikes northwest and dips about $50^{\circ} \mathrm{SW}$. The limestone adjoining the fault is sheared and altered, and that in the footwall has been dragged to a nearly vertical attitude. The fault zone itself is 1 to 3 feet wide and is filled with a mixture of manganese oxides and gangue that probably averages about 35 percent manganese. Lower-grade material was present adjoining the fault and formed the material mined from most of the pit. 
The ore in the east limb of the pit may have been localized by another fault, but this fault appears to be considerably smaller than the first. Most of the ore was stoped from a single bed 4 to 5 feet thick, which was locally replaced by manganese oxides, mostly pyrolusite. There appears to have been relatively little high-grade ore, and most of the material left is a stockwork of manganese oxide veinlets surrounding fragments of altered limestone.

All the ore in the west end of the pit has not been mined, but the amount remaining is difficult to ascertain from present development.

\section{TINTIC STANDARD MINE}

The Tintic Standard, in secs. 15 and 16, T. 10 S., R. 2 W., is one of the principal mines of the Dividend area on the east slope of the East Tintic Mountains. It has been extensively developed for precious and base metals, and the manganese oxides exposed were encountered during the course of these operations. The following data were obtained by engineers of the U. S. Bureau of Mines and by Ralph J. Roberts in 1941.

Most of the ore is reported to be in fault zones that strike $\mathrm{N} 30^{\circ}-$ $40^{\circ} \mathrm{W}$. and dip steeply to the southwest. The manganese oxides replace limestone beds in the Ophir formation near its contact with the Tintic quartzite. Primary manganese minerals have not been found associated with any of the deposits, but rhodochrosite is reported to occur in small quantities at greater depth.

Bodies of manganiferous ore were exposed on the 900-foot and 1,100foot levels, and another occurrence is reported on the now-inaccessible 600 -foot level. Two bodies were cut on the 900 -foot level, one 600 feet north of the main shaft in the 903A8 sill, the other east from the shaft in the 903A2 crosscut. Each of these bodies has been developed sufficiently to indicate that it contains a few thousand tons of ore. In a drift off the 1104B8 raise, manganese oxides were exposed for a distance of 40 feet and were at least 14 feet high and 5 feet wide; the walls were not exposed. Another exposure is reported on the sixth floor of the $1103 \mathrm{~B}$ workings.

The grade of these bodies is best indicated by samples taken by the U. S. Bureau of Mines for metallurgical testing (table 21).

TABLE 21.-Assay by U. S. Bureau of Mines of metallurgical samples from Tintic Standard mine, Tintic district, Utah and Juab Counties, Utah

\begin{tabular}{|c|c|c|c|c|c|}
\hline Sample & $\mathrm{Mn}$ & $\mathrm{SiO}_{2}$ & $\mathrm{Fe}$ & $\mathrm{Pb}$ & $\mathrm{Zn}$ \\
\hline B & $\begin{array}{l}27.5 \\
25.3 \\
13.5\end{array}$ & $\begin{array}{r}11.0 \\
32.8 \\
7.0\end{array}$ & $\begin{array}{r}21.0 \\
9.9 \\
37.5\end{array}$ & $\begin{array}{l}0.0 \\
.0 \\
.5\end{array}$ & $\begin{array}{l}2.85 \\
.60 \\
1.25\end{array}$ \\
\hline
\end{tabular}

A. Sample from $903 \mathrm{~A} 8$ sill.

B. Sample from $903 \mathrm{~A} 2$ crosscut, eighth foor.

C. Sample from 1103B workings, sixth foor. 


\section{FIELDS CLAIMS}

The Fields group consists of five claims: the Graphite Nos. 1 and 2, Franklin, Lexington, and Hermione, owned by Carl Fields, Robert Fields, Jim Bent, and Sam Gardner of Eureka, Utah. The property is in the SW $1 \frac{1}{4}$ sec. 36, T. 9 S., R. 3 W., at an altitude of about 7,200 feet on the north slope of Fremont Canyon, about a mile N. 231/2. W. of Packard Peak. It was examined by the writer in April 1946. The road to the property from the end of Church Street in Eureka would require a small amount of repair to be passable. Although about 25 . tons of ore was stockpiled in 1940, none has been shipped.

The ore occurs in and adjacent to a mass of jasperoid breccia that appears to strike $\mathrm{N} .50^{\circ}-60^{\circ} \mathrm{W}$. and $\operatorname{dip} 40^{\circ}-50^{\circ} \mathrm{NE}$. The jasperoid is heavily stained and cemented by pyrolusite and iron oxides, but the best ore appears to be formed by replacement of a sheared zone on the footwall of the jasperoid. The country rock is thin-bedded limestone that, according to Lindgren and Loughlin (1919), is near the top of the Bluebell dolomite. The jasperoid crops out for 200 feet or so up the ridge to the northwest, and there is sufficient stain and float to suggest that the manganese mineralization may continue in this direction. Other large outcrops of jasperoid extend down the ridge to the southeast, but no manganese was observed below the road.

The ore is soft pyrolusite, probably containing considerable clay and sheared limestone as well as jasperoid. The part of the ore in the jasperoid will inevitably be high in silica and difficult to hand-sort, but the ore below it in the sheared zone should be directly minable. A 2-ton sample of the ore piled on the dump and in the chute taken by the Bureau of Mines for metallurgical tests assayed 22.2 percent $\mathrm{Mn}, 19.6$ percent $\mathrm{SiO}_{2}, 16.0$ percent $\mathrm{CaO}, 2.1$ percent $\mathrm{Fe}, 6.1$ percent $\mathrm{Al}_{2} \mathrm{O}_{3}$, and 0.2 percent $\mathrm{Zn}$.

This material was probably fairly representative of the product obtainable by simple selective mining. Ore was encountered in one small pit to the north of the main pit, suggesting the possibility that the hanging wall of the jasperoid may also be mineralized.

\section{BLACR JACR (EMPIRE) MINE}

The Black Jack, or Empire, mine is in the center of the $W 1 / 2$ sec. 30 , T. 10 S., R. 2 W., about 1,600 feet south-southeast of the town of Mammoth. It was formerly owned by the Knight Investment Co., but is now the property of the International Smelting and Refining Co. The principal workings are a 1,400-foot shaft, with more than a mile of drifts and crosscuts, and a 2,100-foot adit. All these workings were driven before 1914 in search of precious and base metals and, so far as known, yielded no manganese. The property was visited briefly by the writer in April 1946. 
Four hundred feet south of the Black Jack shaft, at an altitude of 6,900 feet, is an open-cut 120 feet long, 50 feet wide, and 50 feet deep that extends into the hill from the road. This working is on an outcrop of manganiferous iron ore in a highly altered and silicified zone at the contact of the Ordovician Opohonga limestone with a narrow tongue of monzonite. The mineralized area is irregular but appears to be elongate in a north-south direction and to dip steeply to the west. The material exposed consists of crusts, coatings, and spongy masses of limonite and waddy pyrolusite in altered limestone and clay. The average manganese content probably does not exceed 15 percent.

What appears to be the same zone of mineralization was encountered 100 feet below the open pit in an adit known as the "Iron tunnel." The portal of this adit is 300 feet southwest of the open-cut. The adit was driven 369 feet $\mathrm{N} .70^{\circ} \mathrm{E}$. and passed through a manganiferous zone 35 feet wide at a distance of 288 feet from the portal. This zone was explored for 80 feet along the strike to the north and 50 to 75 feet up the dip. The grade of the material is probably about 15 percent manganese.

A 2-ton sample of the ore zone encountered in the Iron tunneI taken by the Bureau of Mines for metallurgical tests assayed 19.27 percent $\mathrm{Mn}, 17.8$ percent $\mathrm{SiO}_{2}, 10.5$ percent $\mathrm{Fe}, 17.5$ percent $\mathrm{Al}_{2} \mathrm{O}_{3}$, 0.15 percent $\mathrm{Zn}$, no $\mathrm{Ba}$, and 0.136 percent $\mathrm{P}$.

The material was found to be unsuitable for concentration by oredressing methods. However, it could be used directly in the blast. furnace if material of better grade were not available.

\section{WHITE CLOUD CLAIM}

The White Cloud is a patented claim, owned by C. W. Jenkins, of Los Angeles, Calif., along the creek just south of Sunrise Mountain in the $\mathrm{NW} 1 / 4 \mathrm{NW} 1 / 4$ sec. 20 , T. 11 S., R. $2 \mathrm{~W}$. It was examined by the writer in April 1946. One adit begins at the level of the creek and extends into the hill to the south. The other adit begins about 25 feet above the creek bed and extends north; it is caved at the portal. Jenkins is reported to have shipped about 150 tons of ore from this property in 1931, but it was mixed with ore from other properties and the tonnage and grade are uncertain.

The two adits follow a vein that strikes $\mathrm{N} .15^{\circ} \mathrm{E}$. and dips $70^{\circ}$ NW. The country rock is latite of Tertiary age. The vein material is coarsely crystalline quartz showing comb structure and containing numerous drusy cavities. These openings are partly filled or encrusted with manganese and iron oxides. Fine sooty pyrolusite is the only manganese mineral recognized. Most of the pyrolusite is so intimately intergrown with the quartz that hand sorting would 
be difficult and the product would inevitably be high in silica. The average grade of the vein exposed is probably less than 10 percent manganese. A small quantity of ore averaging 30 percent manganese could be obtained by selective mining and sorting.

\section{BLACK JACK (WINBERG) PROPERTY}

The Black Jack, or Winberg, property is in the NW1/4 sec. 20, T. 11 S., R. 2 W. It is owned by A. W. Winberg, B. T. Cannon, and John S. Lemmon and consists of at least four claims, two of them lying to the south of the White Cloud mine. Development is confined to those claims over the ridge south of the White Cloud. The property was examined by the writer in 1946 .

The recorded production is given in table 22 .

TABLE 22.-Manganese-ore production, Black Jack (Winberg) property, Tintic district, Utah and Juab Counties, Utah

\begin{tabular}{|c|c|c|c|c|}
\hline Year & Shipper & Destination & $\begin{array}{l}\text { Ore shipped } \\
\text { (long tons) }\end{array}$ & $\begin{array}{c}\text { Grade } \\
\text { (percent Mn) }\end{array}$ \\
\hline \multirow[t]{2}{*}{$\begin{array}{l}1929 \\
1930\end{array}$} & $\begin{array}{l}\text { Thomas E. Chatwin } \\
\text { Do }\end{array}$ & $\begin{array}{c}\text { Columbia Steel Co } \\
\text { do }\end{array}$ & $\begin{array}{r}47 \\
41 \\
318\end{array}$ & $\begin{array}{l}35.2 \\
37 \\
35.2\end{array}$ \\
\hline & Total and average. & & 406 & 35.3 \\
\hline
\end{tabular}

The vein, which appears to be the same as that worked in the White Cloud, is exposed in open pits and trenches for a distance of 200 feet. A shaft originally extended to a depth of 50 feet, and the vein, which strikes $\mathrm{N} .10^{\circ} \mathrm{E}$. and dips $60^{\circ} \mathrm{W}$., was stoped for short distances both to the north and to the south. The wall rocks are latite of Tertiary age. The vein matter is coarse drusy quartz, like that in the White Cloud, coated and filled with manganese and iron oxides. The manganese mineral pyrolusite forms mammillary crusts and coatings or dense masses.

There is nothing to indicate whether or not all the ore was mined out.

\section{IRON BLOSSOM MINE}

Manganese oxides were identified underground and on the dumps of the Iron Blossom mine in the W1/2 sec. 29, T. $10 \mathrm{~S}$., R. $2 \mathrm{~W}$., by Lindgren and Loughlin (1919).

\section{IRON KING MINE}

Manganese oxides occur in the Iron King mine, which is the property of the Eureka Consolidated Mining Co., in the center of sec. 21, T. 10 S., R. 2 W. The adit of the Iron King follows a fault that strikes east and dips $70^{\circ} \mathrm{S}$. in the Bluebell dolomite. The mineralized zone is 5 to 12 feet wide and is filled with clay and gouge containing pods and bands of iron-manganese oxides. The manganese content, 
however, is commonly less than 5 percent, and the material does not appear to constitute a commercial source of manganese. The property was examined briefly by Ralph J. Roberts in 1941 .

\section{APEX STANDARD CLAIMS}

The Apex Standard claims are in the E $12 \mathrm{NW}^{1 / 4}$ sec. 22, T. $10 \mathrm{~S}$, R. $2 \mathrm{~W}$. They are the property of the Chief Consolidated Mining. Co. and were leased in 1930 to C. W. Jenkins. About 10 carloads of ore containing 11 to 12 percent manganese are reported to have been shipped; however, these shipments were not identified in the records of production for that year and were probably mixed with ore from other mines.

\section{NORTH TINTIC CLAIMS}

The North Tintic group of claims, a property of the North Tintic Mining and Milling Co., is in the center of sec. 4, T. 10 S., R. 2 W., half a mile north of the Tip Top tunnel in Homansville Canyon. A foot of fair manganese oxide ore was visible in a 75-foot adit. There were also several jaspery outcrops and sufficient float to encourage. the search for bodies of commercial size. None of sufficient size and grade to be minable was visible in 1918, according to unpublished notes by J. T. Pardee.

\section{WASATCH COUNTY}

GREY HAWK PROPERTY

The Grey Hawk property is at an altitude of 10,000 feet on the southwest side of the Uinta Mountains. It is reported by engineers. of the U. S. Bureau of Mines to be in sec. 23, T. 1 N., R. 11 W. (Uinta. special meridian), near the road to Wolf Creek, about 4 miles northeast of the Lake Creek ranger station. The owners are Fred and Charles Haun and Hy and Verald Lamb.

The ore is reported to be concentrated along a brecciated zone in red sandstone. Two samples taken by the U. S. Bureau of Mines. assayed 6.5 and 9.0 percent manganese. A 2-ton sample taken by the U. S: Bureau of Mines for metallurgical testing contained 5.5 percent $\mathrm{Mn}, 0.6$ percent $\mathrm{Fe}, 73.4$ percent $\mathrm{SiO}_{2}, 2.8$ percent $\mathrm{Al}_{2} \mathrm{O}_{3}$, and 1.65 percent $\mathrm{Ba}$.

It was found that a "combined flotation and tabling treatment recovered 61.6 percent of the manganese in a product that, when sintered, assayed plus 40 percent manganese." The sinter contained 10.5 percent barium, according to unpublished reports in the files of the U. S. Bureau of Mines.

\section{EAST STAR NO. 1 PROPERTY}

Arthur Warr and Charles $\mathrm{H}$. Kilken are the owners of a manganese property known as the East Star No. 1, located in sec. 13, T. 2 S., 
R. $11 \mathrm{~W}$. (Uinta special meridian). Manganese oxides are reported to occur in loose conglomerate in a forested area of poor exposures. Two samples were taken by engineers of the U. S. Bureau of Mines: they assayed 4.0 and 10.6 percent manganese.

\section{WASHINGTON COUNTY}

\section{BLACK BEAUTY NO. 1 CLAIM}

The Black Beauty No. 1 claim is in the NE1/4 SW $1 / 4$ sec. 32, T. 40 S., R. 17 W., a quarter of a mile northwest of the Santa Clara River and about $1 \frac{1}{2}$ miles west of the town of Gunlock. It is owned by J. P. Vernon, Orvil Levitt, and Arthur Nickey, of Gunlock. The property was examined by W. H. Myers in 1941 and by the writer in May 1946.

Manganese oxides were found scattered on the surface of the ground in several gullies on the east side of a small wash that joins the Santa Clara River from the north, just east of Manganese Wash. This wash follows approximately the contact between the Navajo sandstone (Baker, Dane, and Reeside, 1936, pp. 21-23), which crops out to the south and west, and the Carmel formation, which contains the manganese oxides and crops out to the northeast. The Navajo sand'stone strikes nearly east and dips $20^{\circ} \mathrm{S}$., and the Carmel formation 'strikes $30^{\circ} \mathrm{N}$. and dips flatly to the northeast.

The lower 200 feet of the Carmel formation consists of red and white silty clay and shale, containing several beds and lenses of gypsum.

The manganese-bearing lenses occur at a horizon about 50 feet above the base of the formation and are found discontinuously along the strike for a distance of several hundred feet. About 20 feet above the manganiferous zone is a fairly continuous bed of gypsum 5 to 10 feet thick.

The manganese oxides occur as lenticular masses up to 5 inches thick, intimately associated with pinkish celestite. Only one specimen was studied, so that it is not known whether celestite occurs in all the manganiferous lenses. Many of the manganiferous fragments on the surface are thoroughly coated with oxides and from both appearance and weight were thought to be solid ore. However, freshly broken surfaces show that the material consists of many bands of pinkish-brown celestite $1 / 8$ to 1 inch thick separated by bands $1 / 25$ to $1 / 2$ inch thick of manganese oxide mixed with a little celestite. The grade of carefully selected ore probably would not exceed 35 percent manganese, owing to the large amounts of material other than manganese oxide. Moreover, the lenticular and discontinuous nature of the outcrops suggests that the quantity of manganese present is relatively small.

The origin of the manganese is not readily apparent. Its occurrence for some distance at a limited horizon, however, and the lack of cross- 
cutting relationships or structural control suggest that the manganese is syngenetic and was deposited with the enclosing beds.

\section{WALLACE CLAIMS}

The Wallace group of 18 claims is on the west slope of Upper Smith Mesa, 9 miles by airline northeast of Toquerville, Utah. It is owned by Kate and H. M. Wallace, of Toquerville, and was leased in 1941 to H. E. Grant, of Salt Lake City. The property was examined by engineers of the U. S. Bureau of Mines. The manganese occurs as high-grade nodules scattered through the talus from the mountain. Only one pit exposes manganese in place.

The ore occurs in the thin-bedded, varicolored shale of the Chinle formation, and the float is usually high in grade, often assaying 50 percent or more manganese. There has been no production, and the showings do not suggest that a large quantity of ore is present. The following assay, made by the U. S. Bureau of Mines, is reported to be typical: 49.95 percent $M n, 1.0$ percent $Z n, 0.2$ percent $S, 1.04$ percent Fe, 4.8 percent $\mathrm{SiO}_{2}, 0.04$ percent $\mathrm{P}_{2} \mathrm{O}_{5}$, and 1.26 percent $\mathrm{Al}_{2} \mathrm{O}_{3}$.

\section{WEBER COUNTY}

\section{PAYDAY CLAIMS}

The Payday group of 13 claims is on the point of the ridge just east of the junction of Causey Creek and the south fork of the Ogden River, 13 miles northeast of Huntsville. It is in the $\mathrm{SE} / 4 \mathrm{NE} / 4$ sec. 34, T. 4 N., R. 3 E. The property was originally operated by the Shamrock Mining Co. in 1917 and 1918 and at that time was known as the Shamrock mine. Carl Slater, of Ogden, reports that about 100 tons of ore was shipped to a paint company in Ogden in 1918. The claims were later relocated by Vernon Taylor, George Higley, and associates, but the only shipments were made in the fall of 1944 by $\mathrm{H}$. DeWitt Trotter. The amount and grade of the ore shipped are unknown. The property was examined by the writer in April 1946.

The best exposures are in an open pit 40 feet across and 25 feet deep on the nose of the sharp ridge. This pit exposes the contact of Cambrian limestone and the overlying Almy formation of early Eocene age. The limestone bedrock strikes $45^{\circ} \mathrm{N} .-50^{\circ} \mathrm{E}$. and dips $30^{\circ}-40^{\circ}$ $\mathrm{NW}$. Its upper surface is highly irregular in detail, showing sharp pinnacles and deep solution channels, but from a distance it appears to be a fairly smooth surface dipping a few degrees to the west. The Almy conglomerate consists of rounded boulders an inch to 2 feet in diameter loosely cemented by sand, gravel, and a little clay. Some of the boulders have been fractured, but there is no indication that the fractures affect the bedrock, and the movement is probably the result of local solution and slumping. The geology of the area surrounding the deposit has been described by Eardley (1944). 
The manganese oxides occur as cement between the boulders of the conglomerate and as irregular concretionary masses in a few clayey zones. These masses are quite striking in appearance, for they consist of irregular slaggy cores of dense blue-black psilomelane around and within which there is a layer of shiny black crystalline pyrolusite terminating in tabular crystals. Much of the cementing manganese oxide is friable and separates readily from the conglomerate. A 2-ton sample of the better-grade material from the walls of the pit was taken by the Bureau of Mines for metallurgical tests. It contained 39.5 percent $\mathrm{Mn}, 17.2$ percent $\mathrm{SiO}_{2}, 0.30$ percent $\mathrm{Fe}, 0.14$ percent $\mathrm{P}$, and 6.1 percent $\mathrm{Ba}$.

Several other pits were dug a short distance up the ridge to the northeast and along the contact as much as half a mile to the northeast. Most of these pits have caved so as to obscure the ore in place, but material on the dumps suggests that the ore encountered was similar to that already described, although not so high in grade. Mr. Taylor reports that manganese oxides occur also in the base of the conglomerate across Causey Creek to the west and across Ogden River to the south and southwest.

Although a small quantity of waddy manganese oxide was observed along bedding planes and fractures of the limestone beneath the conglomerate, there is no evidence of major fractures in the bedrock, and nowhere has ore been exposed more than a few feet below the contact. An adit which was started in the limestone a short distance below the main open pit is reported to be almost barren. Although there is nothing to indicate the origin of the deposit, it seems likely that the manganese minerals were deposited by ground water moving through the conglomerate above the limestone contact. 


\section{SELECTED BIBLIOGRAPHY}

The following is a selected list of publications dealing with or related to manganese in western Utah, together with a few more general references. Those marked with an asterisk $\left(^{*}\right)$ are cited in the text.

*Barer, A. A., Dane, C. H., and Reeside, J. B., Jr., 1936, Correlation of the Jurassic formations of parts of Utah, Arizona, New Mexico, and Colorado: U. S. Geol. Survey Prof. Paper 183.

*Baker, A. A., Duncan, D. C., and Hunt, C. B., Manganese deposits of southeastern Utah: U. S. Geol. Survey Bull. 979-B (in preparation).

*Boutwell, J. M., 1905, Economic geology of the Bingham mining district, Utah: U. S. Geol. Survey Prof. Paper 38.

*__ 1912, Geology and ore deposits of the Park City district, Utah: U. S. Geol. Survey Prof. Paper 77.

*Butler, B. S., 1913, Geology and ore deposits of the San Francisco and adjacent districts, Utah: U. S. Geol. Survey Prof. Paper 80.

*Calkins, F. C., and Butler, B. S., 1943, Geology and ore deposits of the Cottonwood-American Fork area, Utah: U. S. Geol. Survey Prof. Paper 201.

*Callaghan, Eugene, 1938, Manganese deposits of the Drum Mountains, Utah: Econ. Geology, vol. 33, no. 5; pp. 508-521.

*Callaghan, Eugene, and Thomas, H. E., 1939, Manganese in a thermal spring in west-central Utah: Econ. Geology, vol. 34, no. 8, pp. 905-920.

*Crawford, A. L., and Buranek, A. M., 1942, Manganese deposits northwest of Panguitch, Utah: Utah Dept. Publicity and Industrial Development Circ. 11.

Dean, R. S., Devanex, F. D., and Coghill, W. H., 1934, Manganese; its occurrence, milling, and metallurgy, Part 5, Bibliography: U. S. Bur. Mines Inf. Circ. 6772, pp. 309-334.

*EardLeY, A. J., 1944, Geology of the north-central Wasatch Mountains, Utah: Geol. Soc. America Bull., vol. 55, no. 7, pp. 819-894.

Engineming and Mining Journal, 1918, Manganese ores in Utah, vol. 106, p. 706.

*Fleischer, Michael, and Richmond, W. E., Jr., 1943, The manganese oxide minerals, a preliminary report: Econ. Geology, vol. 38, no. 4, pp. 269-286.

*Fry, Eugene, and Wilson, S. R., 1949, Investigation of the Huber-Rydalch manganese deposits, Tooele County, Utah: U. S. Bur. Mines Rept. Inv. 4601 .

*Gilluly, JAmes, 1932, Geology and ore deposits of the Stockton and Fairfield quadrangles, Utah: U. S. Geol. Survey Prof. Paper 173.

*Godpard, E. N., 1940, Manganese deposits at Philipsburg, Granite County, Mont.: U. S. Geol. Survey Bull. 922-G.

*Harder, E. C., 1910, Manganese deposits of the United States: U. S. Geol. Survey Bull. 427.

Head, R. E., 1941, Physical characteristics of some low-grade manganese ore: U. S. Bur. Mines Rept. Inv. 3560.

Healey, M. V., and Johns, A. L., 1930, Selected bibliography and map of manganese deposits of the United States by districts: U. S. Bur. Mines Inf. Circ. 6274.

*Hewetr, D. F., and Pardee, J. T., 1933, Manganese in Western hydrothermal ore deposits, in Ore deposits of the United States (Lindgren volume), pp. 671-682, Am. Inst. Mir. and Met. Eng.

945346-51-5 
*KInG, W. H., 1947, Drum Mountain manganese project, Juab County, Utah: U. S. Bur. Mines Rept. Inv. 3993.

*Lindgren, Waldemar, and Loughlin, F. G., 1919, Geology and ore deposits of the Tintic mining district, Utah: U. S. Geol. Survey Prof. Paper 107.

*Marselt, R. E., 1932, Geology of the Jordan Narrows region, Traverse Mountains, Utah (unpublished thesis, University of Utah).

*Pabst, Adolf, 1938, Orientation of bixbyite on topaz: Am. Mineralogist, vol. 25 , no. 5 , pp. $342-347$.

*Palache, Charles, 1934, Minerals from Topaz Mountain, Utah: Am. Mineralogist, vol. 19, no. 1, pp. 14-15.

*Pardee, J. T., 1921, Deposits of manganese in Montana, Utah, Oregon, and Washington: U. S. Geol. Survey Bull. 725-C.

*Richardson, G. B., 1941, Geology and mineral resources of the Randolph quadrangle, Utah-Wyo.: U. S. Geol. Survey Bull. 923.

Schlarn, David, 1946, Cobalt content of manganese ores, in Schlain, David, and others; Recovery of cobalt from manganese ores in the production of electrolytic manganese: U. S. Bur. Mines Rept. Inv. 3866.

Schrader, F. C., Stone, R. W., and Sanford, Samuel, 1917, Useful minerals of the United States: U. S. Geol. Survey Bull. 624, pp. 298-309.

U. S. Bureau of Mines, Minerals Yearbook, 1932 to date. Continuation of Mineral Resources of the United States.

U. S. Geological Survey and U. S. Bureau of Mines, Mineral Resources of the United States. Published annually by the Survey for the years 18821923 and by the Bureau of Mines for the years 1924-1931. See also U. S. Bureau of Mines, Minerals Yearbook.

Wayland, R. G., 1942, Composition, specific gravity, and refractive indices of rhodochrosite; rhodochrosite from Butte, Mont.: Am. Mineralogist, vol. 27, no. 9 , pp. $614-628$.

WELD, C. M., and others, 1920, Manganese: Uses, preparation, mining costs, and the production of ferro-alloys: U. S. Bur. Mines Bull. 173.

WhEELER, H. L., 1919, Bibliography of the occurrence, geology, and mining of manganese with some references on its metallurgy and uses: Econ. Geology, vol. 14, no. 3, pp. 245-261.

Zimmerly, S. R., Vincent, J. D., and Schack, C. H., 1942, Concentration of manganese ores from the Drum Mountain district, Utah: U. S. Bur. Mines Rept. Inv, 3606. 


\section{N D EX}

A

Abraham Hot Spring deposit.
Acknowledgments...
Age.
A pex Standärd claims

\section{B}

Baby Elephant deposit. See Black Rock claims.

Beaver County, deposits in.

Bedded deposits

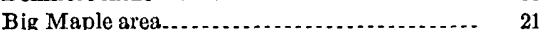

Bixbyite.

9

Black Beauty No. 1 claim.

Black Boy mine. See Staats and Pratt mines.

Black Diamond mine.

Black Hawk claim (Detroit district)

Black Jack (Empire) mine . . . . . . . . . . . . . . . 5 52-53

Black Jack (Gregory) claims . . . . . . . . . . . . . . 23

Black Jack (Guy) mine. See Guy group.

Black Jack (Kendall-Duvall) claims.

Black Jack (Morgan-Cromar) claims

Black Jack (Neilson) claims . . . . . . . . . . . . . . . 25-26

Black Jack (Skougard) claims. . . . . . . . . . . . . . . . 20

Black Jack (Winberg) property . . . . . . . ... 54

Black Ledge claims

Black Rock (Baby Elephant, Strang, Evening Star, Huber-Rydalch) claims. .... 40-41

Black Rock (Shotwell) deposit . .............. 20

Blackbird claims . ...................... 32

Blackhawk claim (Iron County) ........... 24

Blacksmith Fork area . . . . . . . . . . . . . . . . 21-22

Blue Miami Moon No. 1 claim . . ............ 31-32

Braunite.

\section{C}

Cache County, deposits in.

21-22

Calcite, manganoan

Carbonates, manganese, descriptions of ...... 9 oxidation of

$10-11,15$

Classification.

- 11-16

Clove prospect.

Columbia district . . . . . . . . . . . . . . . . . . . . 38-39

Cryptomelane. ............. 8-9

\section{$\mathbf{D}$}

Deer Trail claims

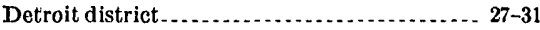

Distribution.

$1-2 ; \mathrm{pl} .1$

Dolomite, manganoan

9
E

Page

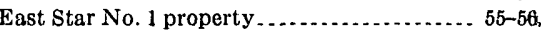

Empire mine. See Black Jack (Empire) mine.

Enrichment. .............................. 10-11

Epigenetic deposits................. 11, 12-13, 15-16

Erickson district. . . . . . . . . . . . . . . . . . . $39-44$

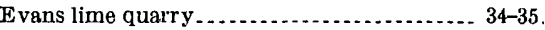

Evening Star deposit. See Black Rock claims.

F

Fields claims

Fullmer prospect. .......................... 22

Future.................................... 16-18

Garfield County, deposits in .............. 22-23

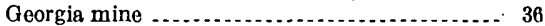

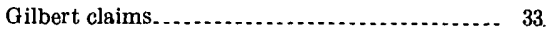

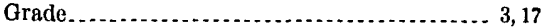

Gregory claims. See Black Jack (Gregory) claims.

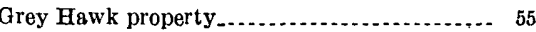

Guy group. . . . . .

$\mathbf{H}$

Hawkins claims . ........................... 22

Huber-Rydalch deposit. See Black Rock claims.

Hydrothermal deposits, oxidized . .......... 12,15.

\section{I}

Indian Boy claim

Investigation, extent of . ...................

Iron Blossom mine. . . . . . . . . . . . . . . . . . . . . 54 .

Iron County, deposits in. . . . . . . . . . . . . . . 23-24

Iron Lily property. See Susie $Q$ claims.

Iron King mine

$\mathbf{J}$

Joe Louis claim _.......

Juab County, deposits in ....... 24-31, 39-44, 48-55.

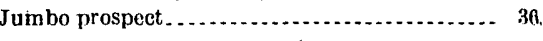

$\mathbf{K}$

Kendall-Duvall claịms. See Black Jack (Kendall-1)uvall) claims.

I

Lakeview claims. . . . . .

Last Chance property . . . . . . . . . . . . . . . . 30-31

Long Ridge mine. See Trotter mine.

Loring property. See Georgis mine. 
M

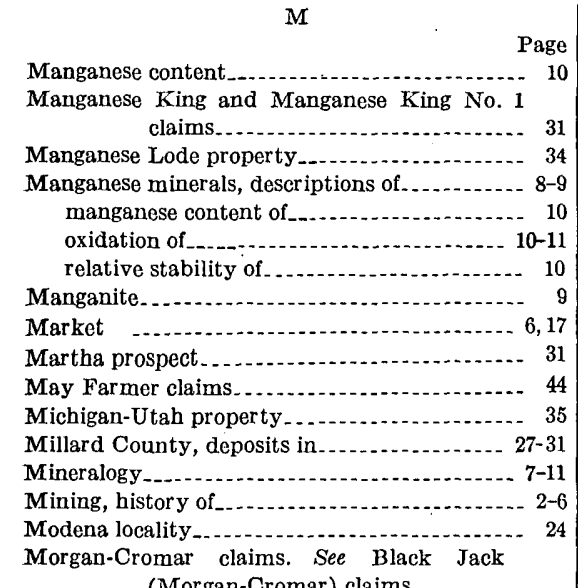
(Morgan-Cromar) claims.

\section{$\mathrm{N}$}

Neilson claims. See Black Jack (Neilson) claims.

Noonday prospect.

North Tintic claims.

Occurrence

Ontario mine

Ophir Hill mine-.

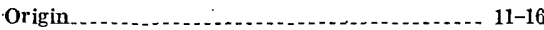

Orme property $\ldots \ldots \ldots \ldots$

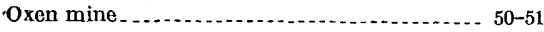

Oxidation.............................. 10-11,15

Oxides, manganese, descriptions of . ......... 8-9

\section{$\mathrm{P}$}

Park City district

Payday claims . . . . . . . . . .

Piute County, deposits in .................... 31-33

Pratt mine. See Staats and Pratt mines.

Price

Production

See also individual mines.

Psilomelane.

Psilomelane-tyne minerals, term defined Pyrolusite

\section{$Q$}

Queen Mary claims...-

Queen of the West claim

\section{$\mathbf{R}$}

Reserves.

Rhodochrosito

Rhodonite

Rich County, deposits in

6,18

$2-6$ 16-18
Page

Salt Lake County, deposits in ... . . . . . . . 34-35

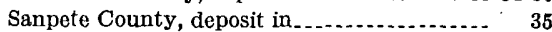

Sevier County, deposits in.................. 36

Sharp mine. .......... 38-39

Shipments of ore, tabulated................ 4-5

Shotwell deposit. See Black Rock (Shotwell) deposit.

Siderite, manganoan......................... 9

Silicate, manganese, description of ......... 9 oxidation of ....................... 10-11, 15

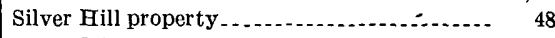

Silver King property ....................... 37

Skougard claims. See Black Jack (Skougard) claims.

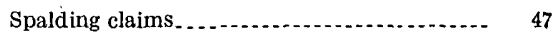

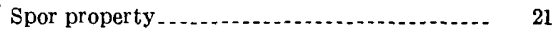

Spring deposits ........... 12, 14-15

See also Abraham Hot Spring deposit and Evans lime quarry.

Staats and Pratt mines. .............. 28-30

Steelville prospect

Strang deposit. See Black Rock claims.

Summit County, deposits in .... . . . . . 36-37

Susie Q claims... _................. 19-20

Syngenetic deposits .................... 11, 13, 13-15

$\mathbf{T}$

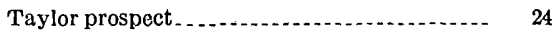

Tintic district. . . . . .

Tintic Standard mine. . . . . . . . . . . . . ..... 51

Tip Top tunnel ....... $49-50$

Tooele County, deposits in . ............... 37-44

Topaz Mountain locality................ 27

Trotter mine. . . . . . . . . . . . . . . . . . . . . . 46-47

Types of deposit.

$\mathrm{U}$

Undetermined origin, deposits of . . . ........ 16

Unnamed deposits ................ 22-23, 24, 35, 36-37

Utah County, deposits in............... 44-55

Utonia claim. ............................. 44

Verdun claim

$\mathbf{V}$

Wallace claims. . . . .

Wasatch County, deposits in .............. 55-56

Washington County, deposits in........... 56-57

weber County, deposits in . . . . . . . . . . 57-58

White Cloud claim ........... 53-54

Wildcat mine...................... 44-46

Winberg property. See Black Jack (Winberg) property.

\section{Y}

3ellow Hornet property 